\title{
Imminent ocean acidification in the Arctic projected with the NCAR global coupled carbon cycle-climate model
}

\author{
M. Steinacher ${ }^{1}$, F. Joos ${ }^{1,2}$, T. L. Frölicher ${ }^{1}$, G.-K. Plattner ${ }^{1, *}$, and S. C. Doney ${ }^{3}$ \\ ${ }^{1}$ Climate and Environmental Physics, Physics Institute, University of Bern, Sidlerstrasse 5, 3012 Bern, Switzerland \\ ${ }^{2}$ Oeschger Centre for Climate Change Research, University of Bern, Erlachstrasse 9a, 3012 Bern, Switzerland \\ ${ }^{3}$ Dept. of Marine Chemistry and Geochemistry, Woods Hole Oceanographic Institution, Woods Hole, MA 02543-1543, USA \\ * now at: Environmental Physics, Institute of Biogeochemistry and Pollutant Dynamics, ETH Zürich, Universitätstrasse 16, \\ 8092 Zürich, Switzerland
}

Received: 22 September 2008 - Published in Biogeosciences Discuss.: 14 November 2008

Revised: 16 March 2009 - Accepted: 26 March 2009 - Published: 6 April 2009

\begin{abstract}
Ocean acidification from the uptake of anthropogenic carbon is simulated for the industrial period and IPCC SRES emission scenarios A2 and B1 with a global coupled carbon cycle-climate model. Earlier studies identified seawater saturation state with respect to aragonite, a mineral phase of calcium carbonate, as a key variable governing impacts on corals and other shell-forming organisms. Globally in the A2 scenario, water saturated by more than $300 \%$, considered suitable for coral growth, vanishes by $2070 \mathrm{AD}$ $\left(\mathrm{CO}_{2} \approx 630 \mathrm{ppm}\right)$, and the ocean volume fraction occupied by saturated water decreases from $42 \%$ to $25 \%$ over this century. The largest simulated $\mathrm{pH}$ changes worldwide occur in Arctic surface waters, where hydrogen ion concentration increases by up to $185 \%(\Delta \mathrm{pH}=-0.45)$. Projected climate change amplifies the decrease in Arctic surface mean saturation and $\mathrm{pH}$ by more than $20 \%$, mainly due to freshening and increased carbon uptake in response to sea ice retreat. Modeled saturation compares well with observation-based estimates along an Arctic transect and simulated changes have been corrected for remaining model-data differences in this region. Aragonite undersaturation in Arctic surface waters is projected to occur locally within a decade and to become more widespread as atmospheric $\mathrm{CO}_{2}$ continues to grow. The results imply that surface waters in the Arctic Ocean will become corrosive to aragonite, with potentially large implications for the marine ecosystem, if anthropogenic carbon emissions are not reduced and atmospheric $\mathrm{CO}_{2}$ not kept below $450 \mathrm{ppm}$.
\end{abstract}

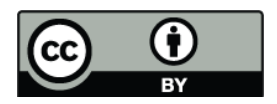

Correspondence to: M. Steinacher (steinacher@climate.unibe.ch)

\section{Introduction}

The continued emissions of $\mathrm{CO}_{2}$ by human activities cause atmospheric $\mathrm{CO}_{2}$ to rise, climate to warm, and the ocean $\mathrm{pH}$ to decrease (e.g. Feely et al., 2008; German Advisory Council on Global Change, 2006; Royal Society, 2005; Orr et al., 2005; Caldeira and Wickett, 2003). Today's atmospheric $\mathrm{CO}_{2}$ concentration of $384 \mathrm{ppm}$ is far above the natural range reconstructed for the last 800000 years (172 to $300 \mathrm{ppm}$; Lüthi et al. (2008); Siegenthaler et al. (2005)) and probably the last 20 million years (Prentice et al., 2001). An important aspect of the human perturbation is its rate of change, as it codetermines the impacts of global warming and elevated $\mathrm{CO}_{2}$ on natural and socioeconomic systems and their capabilities to adapt. The 20th century increase in $\mathrm{CO}_{2}$ occured more than an order of magnitude faster than any sustained change during at least the past 22000 years (Joos and Spahni, 2008). Carbon cycle and climate change projections based on the latest set of mitigation and reference scenarios from the integrated assessment modelling community indicate that $\mathrm{CO}_{2}$ and global mean surface temperature will continue to rise over the 21th century and decadal-scale rates of change in temperature and $\mathrm{CO}_{2}$ will remain high for several decades even for stringent mitigation scenarios (Van Vuuren et al., 2008; Strassmann et al., 2008).

The purpose of this paper is to investigate the consequences of rising atmospheric $\mathrm{CO}_{2}$ and climate change on ocean chemistry and the ocean's acid-base state with the Climate System Model CSM1.4-carbon of the US National Center for Atmospheric Research (NCAR). We investigate how the saturation state of seawater with respect to aragonite, a mineral phase of calcium carbonate $\left(\mathrm{CaCO}_{3}\right)$, will evolve over this century under two IPCC non-intervention

Published by Copernicus Publications on behalf of the European Geosciences Union. 
Table 1. Different levels of aragonite undersaturation $\left(\Omega_{\text {arag }}<1\right)$, atmospheric $\mathrm{CO}_{2}$ concentration and year when these levels are reached in the Arctic for the A2 and B1 scenario. Levels are defined by the area fraction occupied by undersaturated surface waters in at least one month of the year, in the annual mean, and throughout the year.

\begin{tabular}{lccc}
\hline Level (area fraction and seasonal occurrence) & $\mathrm{CO}_{2}(\mathrm{ppm})$ & Year in $\mathrm{A} 2$ & Year in B1 \\
\hline $10 \%, \geq 1$ month & 409 & 2016 & 2018 \\
$10 \%$, annual mean & 428 & 2023 & 2025 \\
$10 \%$, year-round & 450 & 2029 & 2034 \\
$50 \%, \geq 1$ month & 520 & 2047 & 2068 \\
$50 \%$, annual mean & 534 & 2050 & 2085 \\
$50 \%$, year-round & 552 & 2054 & - \\
$100 \%, \geq 1$ month & 634 & 2070 & - \\
$100 \%$, annual mean & 634 & 2070 & - \\
$100 \%$, year-round & 694 & 2080 & - \\
Entire water column & 765 & 2090 & - \\
\hline
\end{tabular}

greenhouse gas emission scenarios. The emphasis here is on the Arctic Ocean, where large changes in $\mathrm{CaCO}_{3}$ saturation (Gangst $\varnothing$ et al., 2008; Steinacher, 2007; McNeil and Matear, 2007; Orr et al., 2008), freshwater balance, and sea ice (Stroeve et al., 2007; Holland et al., 2006) are expected under rising $\mathrm{CO}_{2}$. We also analyze how the ocean volume fraction of different saturation regimes is changing with increasing $\mathrm{CO}_{2}$ and quantify seasonal and interannual variability worldwide.

A particular concern of rising atmospheric $\mathrm{CO}_{2}$ is the impact on marine organisms and marine ecosystems (Doney et al., 2009). Recent work indicates that ocean acidification from the uptake of anthropogenic $\mathrm{CO}_{2}$ has adverse consequences for many marine organisms via decreased $\mathrm{CaCO}_{3}$ saturation, affecting calcification rates, and via disturbance to acid-base physiology (Fabry et al., 2008; Hoegh-Guldberg, 2005; Langdon, 2002). Particularly vulnerable appear organisms that build shells or other structures of calcium carbonate $\left(\mathrm{CaCO}_{3}\right)$ in the relatively soluble mineral forms of aragonite or high-magnesium $\mathrm{CaCO}_{3}$. Examples are pteropods (Orr et al., 2005), a major zooplankton group in high latitudes, corals (Kleypas et al., 2006; Langdon and Atkinson, 2005), and sea urchins (Fabry et al., 2008). Experimental evidence suggests a range of responses to ocean acidification (Fabry et al., 2008, Table 1) such as a reduction in foraminifera shell mass, shell dissolution for pteropods in water undersaturated with respect to aragonite, reduced calcification rates, reduced growth rates, reduced metabolisms, and increased mortality in molluscs or reduced fertility for a number of groups. Responses to acidification are likely to vary across species and life stages. Scleractinian corals were found to survive and recover after experiencing decalcification in acidic water (Fine and Tchernov, 2007). Currently experimental evidence is however limited with regard to the number of species tested at relevant $\mathrm{CO}_{2}$ concentrations.

Uptake of anthropogenic carbon by the ocean changes the acid-base state of seawater. Currently, about a quarter of the anthropogenic $\mathrm{CO}_{2}$ emitted into the atmosphere is taken up by the ocean. The hydrolysis of $\mathrm{CO}_{2}$ in seawater lowers ocean $\mathrm{pH}$, making the oceans less basic (Caldeira and Wickett, 2003). Carbonate ion concentration (Feely et al., 2004) and the saturation state of water with respect to calcium carbonate $\left(\mathrm{CaCO}_{3}\right)$ is decreasing through the reaction:

$\mathrm{CO}_{2}+\mathrm{CO}_{3}^{2-}+\mathrm{H}_{2} \mathrm{O} \rightleftharpoons 2 \mathrm{HCO}_{3}^{-}$.

The $\mathrm{CaCO}_{3}$ saturation state, $\Omega$, is the product of the concentrations of calcium ions $\left(\mathrm{Ca}^{2+}\right)$ and carbonate ions $\left(\mathrm{CO}_{3}^{2-}\right)$ divided by the apparent stochiometric solubility product $K_{\mathrm{sp}}^{\prime}$ :

$\Omega=\left[\mathrm{Ca}^{2+}\right]\left[\mathrm{CO}_{3}^{2-}\right] / K_{\mathrm{sp}}^{\prime}$.

The solubility product $\left(K_{\mathrm{sp}}^{\prime}=\left[\mathrm{Ca}^{2+}\right]_{\mathrm{sat}}\left[\mathrm{CO}_{3}^{2-}\right]_{\mathrm{sat}}\right)$ is either defined for aragonite or calcite, two mineral phases of $\mathrm{CaCO}_{3}$ secreted by marine organisms. The $\mathrm{CO}_{3}^{2-}$ saturation concentration is about $50 \%$ higher for the mineral phase calcite $\left(\Omega_{\text {calc }}\right)$ than for the less stable aragonite $\left(\Omega_{\text {arag }}\right)$. The concentration of $\mathrm{Ca}^{2+}$ is linearly related to salinity and nearly constant. It is thus convenient to express the saturation state as deviation of the $\mathrm{CO}_{3}^{2-}$ concentration from its saturation concentration: $\Delta\left[\mathrm{CO}_{3}^{2-}\right]=\left[\mathrm{CO}_{3}^{2-}\right]-\left[\mathrm{CO}_{3}^{2-}\right]_{\text {sat }}$. Undersaturated seawater $\left(\Omega<1\right.$ or $\left.\Delta\left[\mathrm{CO}_{3}^{2-}\right]<0\right)$ is corrosive to $\mathrm{CaCO}_{3}$ in the absence of protective mechanisms.

The $\mathrm{CaCO}_{3}$ saturation state $\Omega_{\text {arag }}$ is a key variable for assessing biological impacts of ocean acidification. Available experimental and observational evidence suggests that the biogenic production and dissolution of $\mathrm{CaCO}_{3}$ are mainly controlled by the ambient saturation state, rather than by $\mathrm{pH}$ or other factors. This has been shown for corals, coralline algae, coccolithophorids, foraminifera, echinoderms, mesocosm coral reef communities and natural coral reef ecosystems (Kleypas et al., 2006; Schneider and Erez, 2006; Hoegh-Guldberg, 2005; Orr et al., 2005; Gattuso et al., 1998). Tropical coral reef development was associated with 
$\Omega_{\text {arag }} \geq 4.0$ by Kleypas et al. (1999), and Langdon and Atkinson (2005) project a 40-50\% decrease of coral calcification rates by $2065\left(\Omega_{\mathrm{arag}}=3.1\right)$ relative to $\Omega_{\mathrm{arag}}=4.6$, which corresponds to preindustrial conditions (year 1880) in the tropical ocean in their study.

A range of responses is found for pelagic calcifiers under changing $\Omega_{\text {arag }}$ (Fabry, 2008). Recently Iglesias-Rodriguez et al. (2008) reported laboratory evidence that calcification and net primary production per cell in the coccolithophore species Emiliani huxleyi are significantly increased by high $\mathrm{CO}_{2}$ partial pressures. Yet the growth rates were found to be significantly lower at higher $\mathrm{CO}_{2}$ levels. Such changes could have important implications for the overall community production of $\mathrm{CaCO}_{3}$ relative to organic carbon, under increasing $p \mathrm{CO}_{2}$. However, the implied feedback on atmospheric $\mathrm{CO}_{2}$ has been estimated to be small in global modelling studies (Heinze, 2004; Gehlen et al., 2007; Ridgwell et al., 2007).

The main controls on 21 th century $\Omega_{\text {arag }}$ are the uptake of anthropogenic carbon and the subsequent increase in dissolved inorganic carbon (DIC) (Orr et al., 2005). Second order changes in saturation state arises from alterations in the distribution of DIC and alkalinity (Alk) due to a reorganization of the marine biological cycle and ocean circulation as well as ocean warming (decreasing $\mathrm{CO}_{2}$ solubility) and changes in the freshwater fluxes. Changes in sea ice affect $\Omega_{\text {arag }}$ by changing the air-sea gas exchange as well as the freshwater balance. The direct influence of temperature and salinity changes on the $\mathrm{CaCO}_{3}$ solubility product $\left(K_{\mathrm{sp}}^{\prime}\right)$ is negligible.

Large changes in $\Omega_{\text {arag }}$ and $\mathrm{pH}$ have been projected using ocean-only models (Kleypas et al., 1999; Caldeira and Wickett, 2003; Gangst $\varnothing$ et al., 2008). Recently, the impact of climate change on ocean acidification also has been considered (Cao et al., 2007; McNeil and Matear, 2007; Orr et al., $2005,2008)$. In most regions, a relatively small negative climate change feedback is found on changes in $\Omega_{\text {arag }}(\approx 10 \%)$. An exception is the Arctic, where larger changes in $\Omega_{\text {arag }}$ are found for a simulation including climate change compared to one without climate change (McNeil and Matear, 2007). In a recent assessment, Orr et al. (2008) show by combining observations and model results that surface waters in the Arctic will become undersaturated within decades. They present an overview on the evolution of the saturation state in the Arctic with respect to both aragonite and calcite as inferred from three coupled models, including the NCAR CSM1.4-carbon.

Here, we complement earlier studies by using the fully coupled NCAR CSM1.4-carbon model to investigate the evolution of $\Omega_{\text {arag }}$ over the 21 st century for the SRES A2 and $\mathrm{B} 1$ scenarios. In comparison to earlier work, we present a detailed analysis of the changes in the Arctic, including a quantification of underlying mechanisms, assess the global evolution of the ocean volume for different saturation regimes, and analyse spatio-temporal variability in saturation. In the next section, the model and experimental details are described. Then, model results are compared with observations, provid- ing also statistical measures of data-model agreement. In the results section, projected global and regional changes in saturation state are described and climate feedbacks quantified. The change in Arctic saturation state is quantified both from direct model results and by combining observation-based estimates of the current saturation state (Jutterström and Anderson, 2005) with modeled changes following a similar approach as Orr et al. (2005, 2008). Before concluding, the projected anthropogenic changes are compared to modeled natural seasonal and interannual variations.

\section{Methods}

\subsection{The NCAR CSM1.4-carbon model}

Simulations were performed with the coupled climatecarbon cycle model NCAR CSM1.4-carbon (Doney et al., 2006; Fung et al., 2005). The core of the model used in this study is a modified version of the NCAR CSM1.4 coupled physical model, consisting of ocean, atmosphere, land and sea ice physical components integrated via a flux coupler without flux adjustments (Boville and Gent, 1998). The atmospheric model CCM3 is run with a spectral truncation resolution of $\approx 3.75^{\circ}$ (T31 grid) and 18 levels in the vertical (Kiehl et al., 1998). The ocean model is the NCAR CSM Ocean Model (NCOM) with 25 levels in the vertical and a resolution of $3.6^{\circ}$ in longitude and $0.8^{\circ}$ to $1.8^{\circ}$ in latitude (T31x3 grid) (Gent et al., 1998). The sea ice component (CSIM) simulates the dynamic and thermodynamic evolution of ice concentration, thickness, temperature, velocity, and snow cover in response to forcing by the atmosphere and ocean (Bettge et al., 1996).

The model is known to simulate too much ice in the Northern Hemisphere (Weatherly et al., 1998). In particular the ice cover is too extensive in the North Pacific and North Atlantic. There is some contribution to the excess annual mean ice volume through larger-than-observed summer sea ice concentrations in the Arctic Ocean. The simulated preindustrial ice covered area in the Arctic Ocean is about 10\% (summer) to $5 \%$ (winter) larger than estimated by Walsh (1978). The decreasing trend in summer sea ice cover during the last few decades is captured by the model but less pronounced. In the year 2000 the simulated ice covered area is about $40 \%$ (summer) to $10 \%$ (winter) larger than observed. Further, maximum thickness in the Arctic occurs against the Bering Strait, not against the Canadian Archipelago as observed (Weatherly et al., 1998).

The CSM1.4-carbon model combines the NCAR Land Surface Model (LSM) (Bonan, 1996) with the CarnegieAmes-Stanford Approach (CASA) biogeochemical model (Randerson et al., 1997) and a derivative of the OCMIP-2 biotic carbon model (Najjar et al., 2007), where the nutrient uptake has been changed from a restoring to a prognostic formulation and an iron cycle has been added (Doney et al., 

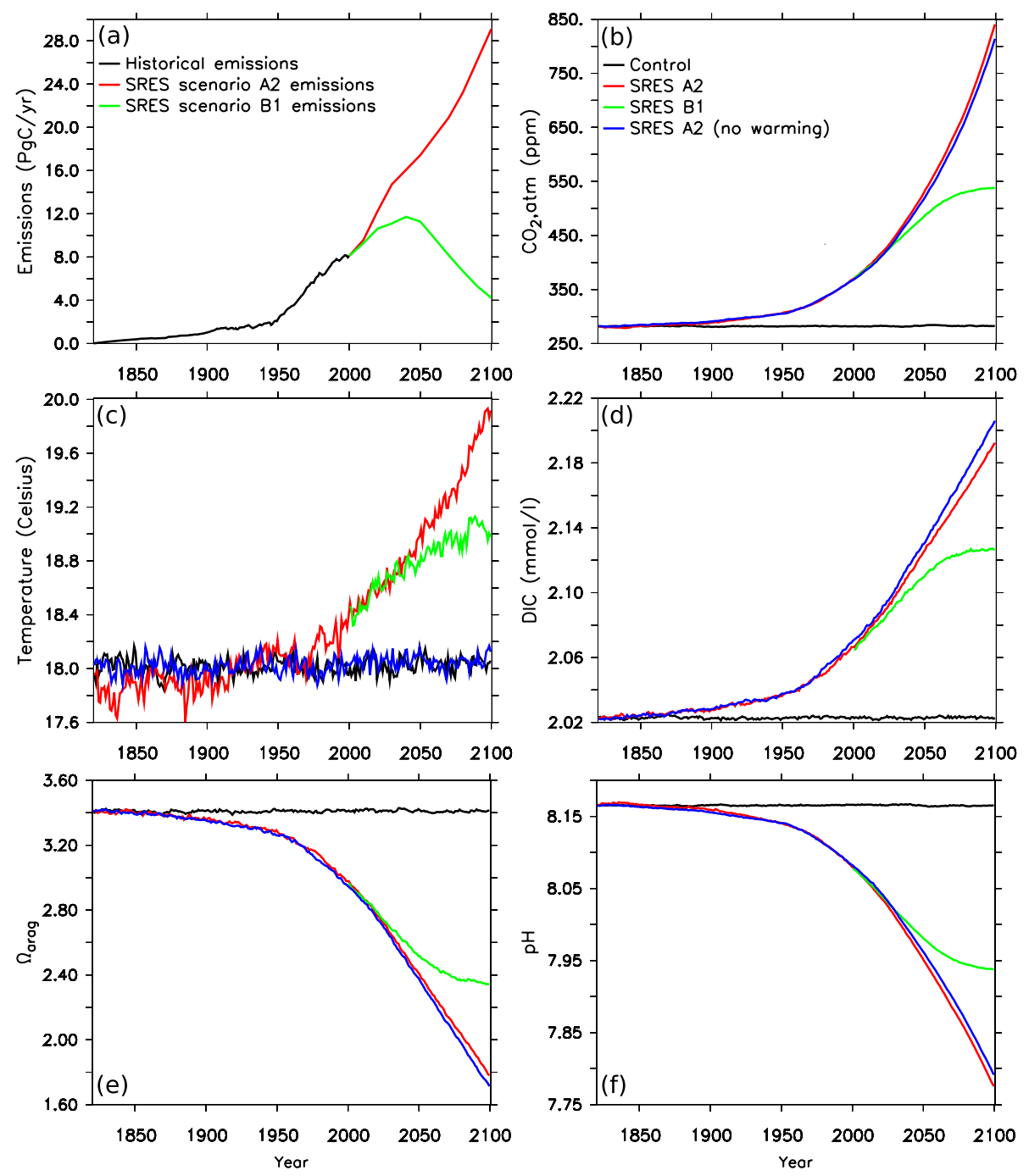

Fig. 1. Prescribed fossil fuel and land use $\mathrm{CO}_{2}$ emissions (a) based on historical data (1820-2000, black) and the SRES-A2 (red) and B1 (green) scenarios (2000-2100). Simulated global annual mean atmospheric $\mathrm{CO}_{2}$ (b), sea surface temperature (SST) (c), dissolved inorganic carbon (DIC) (d), aragonite saturation $\left(\Omega_{\mathrm{arag}}\right)(\mathbf{e})$, and $\mathrm{pH}(\mathbf{f})$ at the ocean surface.

2006). Biological productivity is modulated by temperature, surface solar irradiance, mixed layer depth, and macro- and micronutrients $\left(\mathrm{PO}_{4}^{3-}\right.$, and iron). Following the OCMIP-2 protocols (Najjar et al., 2007), total biological productivity is partitioned $1 / 3$ into sinking particulate organic matter (POC) flux and $2 / 3$ into the formation of dissolved or suspended organic matter, where much of the latter is remineralised within the model euphotic zone. A constant export ratio of $\mathrm{CaCO}_{3}$ to POC of 0.07 and constant Redfield ratios were used (Anderson and Sarmiento, 1994). A ratio of 0.07 is within (Yamanaka and Tajika, 1996; Sarmiento et al., 2002) or at the lower end (Jin et al., 2006; Kwon and Primeau, 2008) of the range given by others. Below the compensation depth of $75 \mathrm{~m}, 90 \%$ of the POC is remineralized within the first $1000 \mathrm{~m}$, following a power-law parametrisation (Mar- tin et al., 1987) and $\mathrm{CaCO}_{3}$ is assumed to decrease exponentially with a depth scale of $3500 \mathrm{~m}$. Any flux of POC or $\mathrm{CaCO}_{3}$ reaching the sea floor is remineralized instantaneously. There is no feedback between changes in saturation state, $\mathrm{pH}$ or other carbonate chemistry variables and the biological carbon cycle implemented.

A sequential spin-up procedure including 1000 years of fully coupled simulation under preindustrial conditions was employed by Doney et al. (2006). Starting from this nearly steady state, four simulations over the period $1820 \mathrm{AD}$ to 2100 AD were performed: (1) a 280 year long control simulation, two simulations with historical emissions over the industrial period followed by the (2) A2 IPCC emission scenario and (3) B1 IPCC emission scenario, and (4) a SRES A2 "no-warming case" simulation, where the concentrations of 
greenhouse gases and other radiative agents were kept at their preindustrial values in the radiation module of the model. Differences in results between this no-warming simulation and the standard SRES A2 simulation are taken to reflect the impact of climate change on carbonate chemistry and other parameters.

The model was driven by emissions of $\mathrm{CO}_{2}$ from fossil fuel and land use change (Fig. 1) as well as by anthropogenic sulfur emissions. Concentrations of the non- $\mathrm{CO}_{2}$ greenhouse gases $\mathrm{CH}_{4}, \mathrm{~N}_{2} \mathrm{O}, \mathrm{CFC}-11$, CFC-12 are prescribed according to reconstructions for 1820 to $2000 \mathrm{AD}$ and as projected from emissions for 2000 to $2100 \mathrm{AD}$. The CFC-11 concentration is scaled to include the forcing of other halogenated species and $\mathrm{SF}_{6}$. Emissions of non- $\mathrm{CO}_{2}$ greenhouse gases were translated to concentration using formulations by Forster et al. (2007). A recurring annual cycle of ozone and natural sulfate aerosol were also included. Over the historical period, solar irradiance changes were prescribed following Wang et al. (2005) and spatially-explicit sulfate aerosols from explosive volcanic eruptions after Ammann et al. (2007). After year 2000, the solar irradiance was kept constant and no volcanic eruptions were assumed. Further details are given by Frölicher et al. (2009).

\subsection{Carbonate chemistry and tracer data}

For model evaluation, the gridded data from the Global Data Analysis Project (GLODAP) (Key et al., 2004) for DIC and Alk, and from the World Ocean Atlas 2001 (WOA01) (Conkright et al., 2002) for temperature $(T)$, salinity $(S)$, phosphate $\left(\mathrm{PO}_{4}^{3-}\right)$ and silicate $\left(\mathrm{Si}(\mathrm{OH})_{4}\right)$ were used. The two data sets were regridded by multi-axis linear interpolation onto the model grid. The gridded GLODAP data have annual resolution and do not include the Arctic.

Carbonate chemistry, $\mathrm{pH}$, carbonate ion concentration, and the saturation state have been calculated offline from modeled or observation-based quantities using the standard OCMIP carbonate chemistry routines (http://www.ipsl.jussieu.fr/OCMIP/phase3/simulations/

NOCES/HOWTO-NOCES-3.html). In these routines, based on work by Dickson (2002), Millero (1995), and Mehrbach et al. (1973), the total pH scale (Lueker et al., 2000) is utilized. The apparent solubility product $K_{\mathrm{sp}}^{\prime}$ is calculated after Mucci (1983) and the pressure dependency of chemical constants after Millero (1995). The observation-based carbonate variables were computed from monthly, seasonal, or annual means, depending on data availability. Annual means have been used for Alk and DIC, as well as for $\mathrm{PO}_{4}^{3-}$ and $\mathrm{Si}(\mathrm{OH})_{4}$ below $500 \mathrm{~m}$. Seasonal means of $T$ and $S$ have been used below $1500 \mathrm{~m}$. For the data-model comparison, annual averages from the simulated monthly carbonate data from 1990 to 1999 were used. Because the CSM model does not include $\mathrm{Si}(\mathrm{OH})_{4}$, a seasonal cycle of observation-based $\left[\mathrm{Si}(\mathrm{OH})_{4}\right]$ from WOA01 has been used in all calculations of simulated $\mathrm{pH}$ and calcium carbonate saturation state.

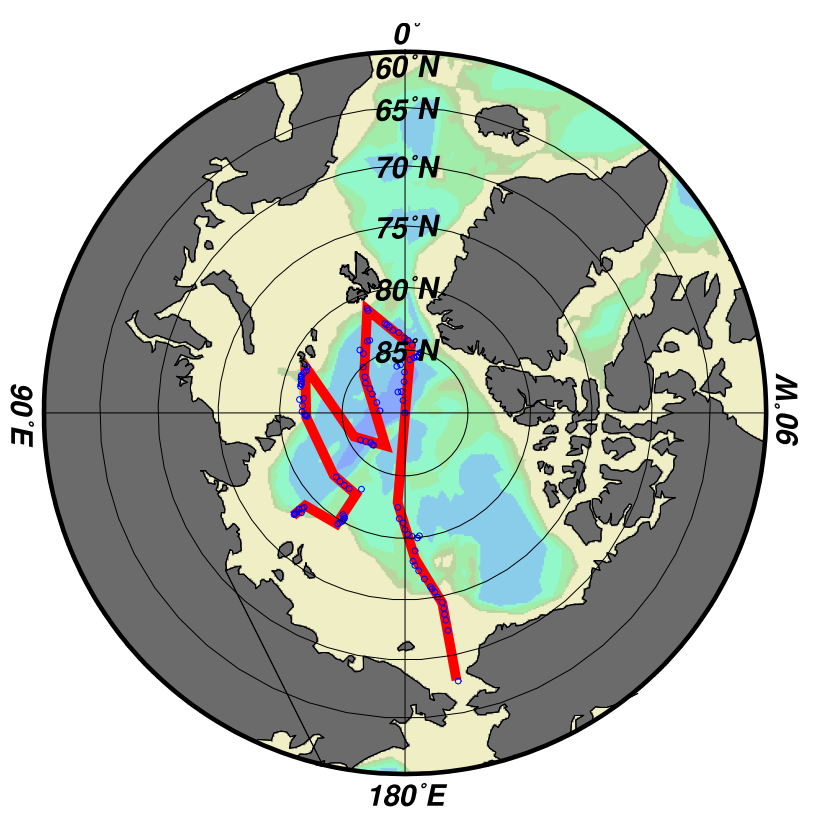

Fig. 2. Investigated Arctic Ocean transect where observation-based data is available from the ODEN-91, AOS-94, and ARCSYS-96 cruises.

Uncertainties in $\left[\mathrm{CO}_{3}^{2-}\right]$ and $\Omega$ arising from this treatment of $\mathrm{Si}(\mathrm{OH})_{4}$ have been estimated to be less than $1 \%$ (Steinacher, 2007).

For the Arctic, observation-based estimates for $\Omega_{\text {arag }}$ and related variables were calculated from $T, S$, Alk, DIC, $\mathrm{PO}_{4}^{3-}$, and $\mathrm{Si}(\mathrm{OH})_{4}$ measurements using the OCMIP chemistry routines and data from the Arctic Ocean Expedition 1991 (ODEN-91, cruise 77DN1991072), Arctic Ocean Section 1994 (AOS-94, cruise 18SN19940726), and the Arctic Climate System Study 1996 (ARCSYS96, cruise 06AQ19960712) (Fig. 2, Jutterström and Anderson, 2005). These data are available from the preliminary CARINA database (http://cdiac.ornl.gov/oceans/CARINA/ Carina_table.html). When not referring to this specific transect where observations are available, the Arctic Ocean is defined to be waters north of $65^{\circ} \mathrm{N}$, except the Labrador Sea and the Greenland, Iceland, and Norwegian (GIN) Seas $\left(<80^{\circ} \mathrm{N}\right.$ and $\left.35^{\circ} \mathrm{W}-18^{\circ} \mathrm{E}\right)$.

\section{Results}

\subsection{Comparison of modeled aragonite saturation and $\mathrm{CO}_{3}^{2-}$ concentration with observation-based esti- mates}

The modeled values and spatial pattern for $\Omega_{\text {arag }}$ and $\left[\mathrm{CO}_{3}^{2-}\right]$ (averaged over the years 1990-1999 in the transient simulation) are compared with the data-based estimates in all major ocean basins (Fig. 3a). The correlation coefficient $r$ between 

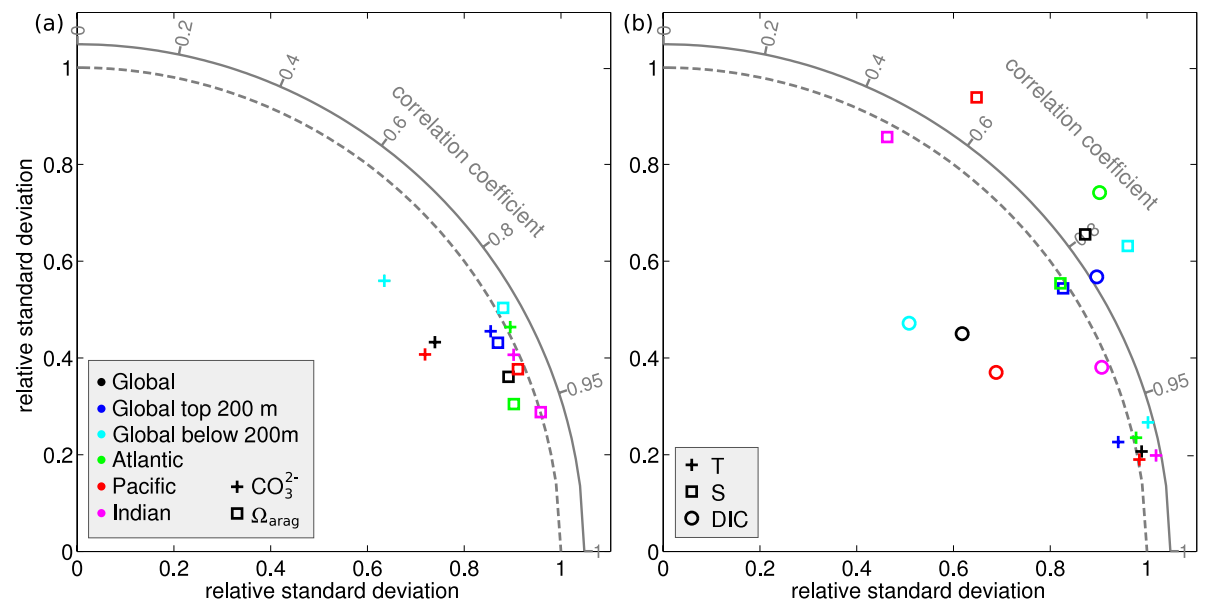

Fig. 3. (a) Taylor diagram (Taylor, 2001) conveying information about the pattern similarity between simulated and observation-based (GLODAP, WOA01) results for $\Omega_{\text {arag }}$ (squares) and $\left[\mathrm{CO}_{3}^{2-}\right]$ (crosses). The observed field is represented by a point at unit distance from the origin along the abscissa. The distance from this point to the other points representing simulated fields, indicates the normalized r.m.s error. The simulated fields are averaged over the model years 1990-1999 and the results are shown for the entire global ocean (black), for the global ocean above (blue) and below (cyan) $200 \mathrm{~m}$ depth, as well as for the three major basins Atlantic (green), Pacific (red), and Indian Ocean (magenta), all of which include the respective part of the Southern Ocean. (b) Taylor diagram comparing simulated temperature (crosses), salinity (squares), and DIC (circles) fields with observation-based data for the same regions.

modeled and data-based $\Omega_{\text {arag }}$ is between 0.90 and 0.95 for the Atlantic, Pacific, and Global Ocean. The model represents the amplitude of variations in $\Omega_{\text {arag }}$ well in all major basins, as indicated by a relative standard deviation close to unity in the Taylor diagram (Fig. 3). Correlation coefficients are somewhat smaller $(0.86$ to 0.91$)$ for $\left[\mathrm{CO}_{3}^{2-}\right]$ than for $\Omega_{\text {arag }}$ because the data-model differences in $\Omega_{\text {arag }}$ decrease with depth relative to the differences in $\left[\mathrm{CO}_{3}^{2-}\right]$. This results because the increase in the pressure-dependent solubility product $K_{\mathrm{sp}}^{\prime}$ with depth decreases the weighting of the larger errors in deep-water $\left[\mathrm{CO}_{3}^{2-}\right]$ (Fig. 4). Model biases in $\left[\mathrm{CO}_{3}^{2-}\right]$ are particularly large in the Pacific where the relative standard deviation is smaller than indicated by observations.

The present distribution of $\Delta\left[\mathrm{CO}_{3}^{2-}\right]$ (Fig. 4) and $\Omega_{\text {arag }}$ is governed by the distribution of DIC and Alk. $\left[\mathrm{CO}_{3}^{2-}\right]$ is approximately proportional to the difference Alk-DIC. Consequently, the nutrient and carbon rich water of the North Pacific thermocline is undersaturated with respect to aragonite, while the relatively nutrient and carbon poor water of the North Atlantic thermocline is oversaturated. The increase of the solubility product $K_{\mathrm{sp}}^{\prime}$ with pressure (depth) leads to a decrease of the saturation state in the deep ocean, although the carbonate ion concentration is relatively homogeneous below $1000 \mathrm{~m}$.

Deviations in modeled and observation-based zonal mean $\left[\mathrm{CO}_{3}^{2-}\right]$ and $\Delta\left[\mathrm{CO}_{3}^{2-}\right]$ are less than $20 \mu \mathrm{mol} / 1$ in the deep Atlantic, the Southern Ocean, and the southern Pacific (Fig. 4). Larger deviations are found in the North Pacific and in the thermocline of the tropical Atlantic. $\left[\mathrm{CO}_{3}^{2-}\right]$ is underesti- mated in the tropical Atlantic related to too high DIC concentration in the model caused by nutrient trapping. On the other hand, the model underestimates export and remineralisation of organic matter in the North Pacific, causing too low DIC concentration and too high $\left[\mathrm{CO}_{3}^{2-}\right]$ in the thermocline and at depth (Frölicher et al., 2009). Correspondingly, the modeled aragonite saturation horizon in the North Pacific is too deep compared with observation-based estimates.

In the Arctic Ocean, the modeled distribution of $\Omega_{\mathrm{arag}}$ corresponds reasonably well to the observation-based estimates (years 1991-1996; Fig. 5). The observations suggest an oversaturation of around 50\% in the top five hundred meter, around $25 \%$ at $1000 \mathrm{~m}$ depth and undersaturation below $2000 \mathrm{~m}$. Horizontal gradients are relatively small along the transect. The model tends to underestimate $\Omega_{\text {arag }}$ at the surface (up to 0.3 ), while below $500 \mathrm{~m} \Omega_{\text {arag }}$ is overestimated by 0.2 to 0.4 . Correspondingly, the simulated saturation horizon is deeper than the observation-based horizon.

\subsection{Projected global mean changes}

Figure 1 provides projected global mean changes for a few key variables that broadly characterize the investigated scenarios. Anthropogenic carbon emissions increase to almost $30 \mathrm{GtC} \mathrm{yr}^{-1}$ by the end of the century for the high-emission SRES A2, whereas emissions peak at around $12 \mathrm{GtC} \mathrm{yr}^{-1}$ and decline thereafter in the more optimistic B1 scenario. Atmospheric $\mathrm{CO}_{2}$ reaches $840 \mathrm{ppm}$ and $538 \mathrm{ppm}$ by the end of the century for the $\mathrm{A} 2$ and $\mathrm{B} 1$ scenario, respectively. Ocean surface DIC content increases on average by $8 \%$ 

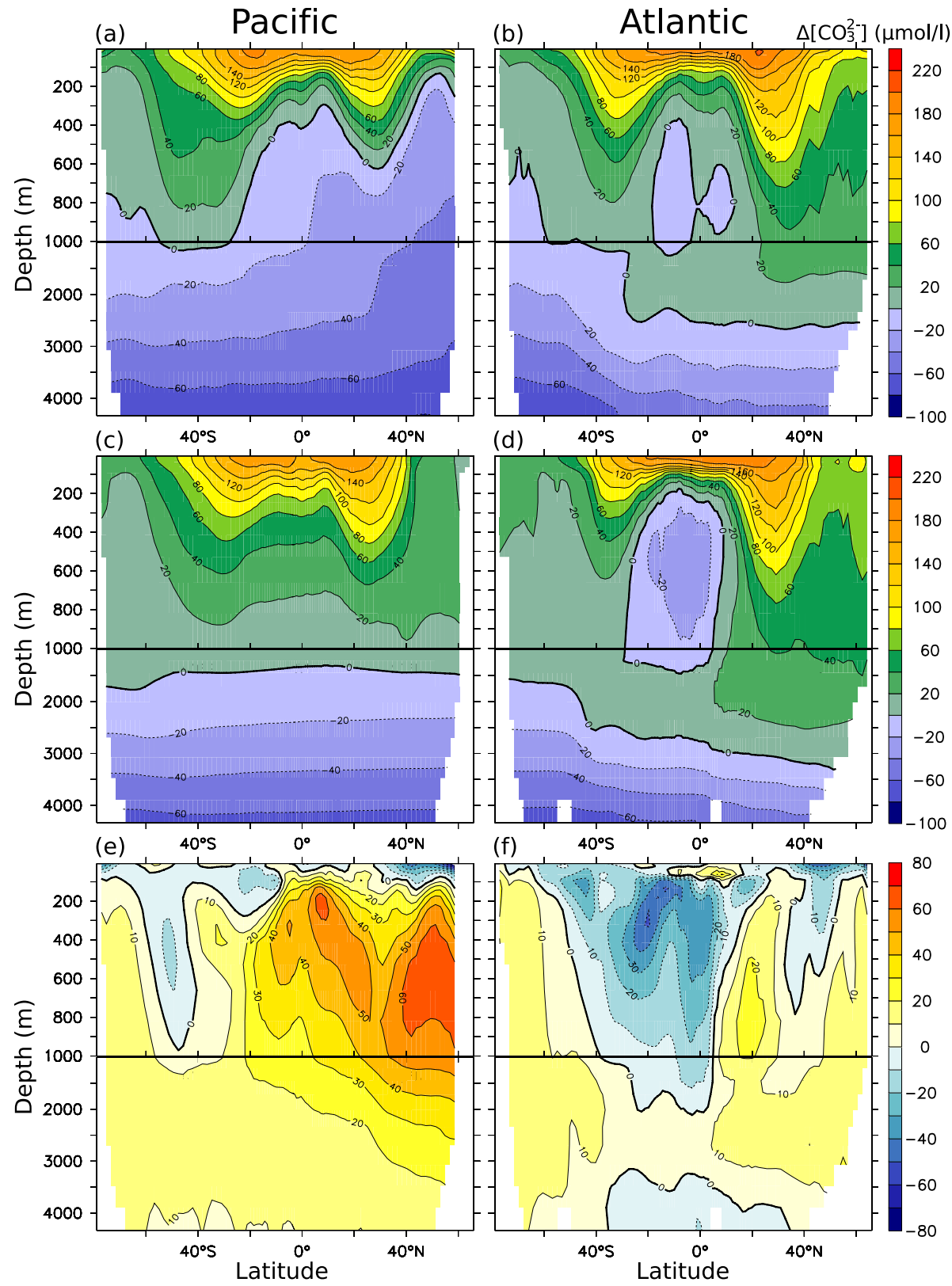

Fig. 4. Meridional sections through the Pacific (left) and the Atlantic (right) showing zonal mean of observed (top) and modeled (middle) supersaturation with respect to aragonite $\left(\Delta\left[\mathrm{CO}_{3}^{2-}\right]\right)$ in $\mu \mathrm{mol} / \mathrm{l}$. The saturation horizon is indicated by the thick line at $\Delta\left[\mathrm{CO}_{3}^{2-}\right]=0$. The bottom row shows the differences between model and measurements (model-observations). Simulated fields are averaged over the model years 1990-1999.

$\left(0.17 \mathrm{mmol} \mathrm{kg}^{-1}\right)$ and by $5 \%\left(0.10 \mathrm{mmol} \mathrm{kg}^{-1}\right)$. Mean aragonite saturation of surface water decreases from a preindus-

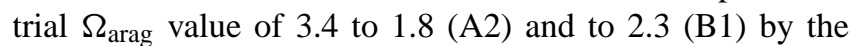
end of the century. Concommitant reductions in $\mathrm{pH}$ are 0.40 and 0.23 units. Global mean surface temperature increase is 1.97 and $0.94^{\circ} \mathrm{C}$, reflecting the low climate sensitivity of the CSM1.4 (Friedlingstein et al., 2006).
Simulated climate change feedbacks on $\Omega_{\text {arag }}$ and $\mathrm{pH}$ are relatively small on the global scale. The $\mathrm{CO}_{2}$ rise is slightly smaller in the no-warming case than in the standard SRES A2 simulation (Fig. 1), consistent with the low climatecarbon cycle feedback of the NCAR CSM1.4 (Fung et al., 2005). The increase in ocean surface DIC by the end of the century is about $8 \%$ larger without climate-feedback and consequently the decrease in surface $\Omega_{\text {arag }}$ is also slightly 

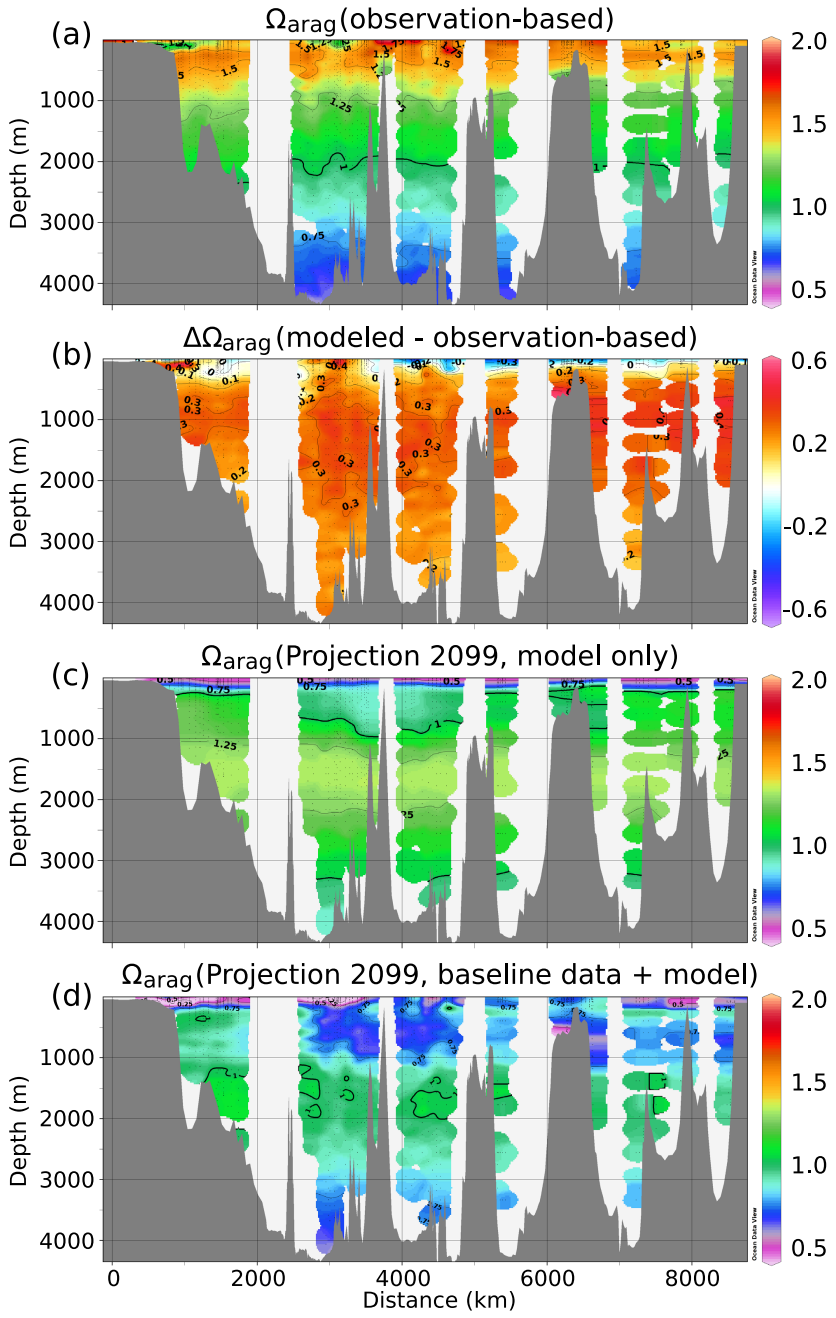

Fig. 5. (a) Observation-based present day aragonite saturation $\left(\Omega_{\text {arag }}\right)$ in the Arctic Ocean based on measurements from the ODEN-91, AOS-94, and ARCSYS-96 cruises during summer. The transect starts near the Bering Strait $(0 \mathrm{~km})$, leads then across the North Pole $(2500 \mathrm{~km})$ to Spitsbergen $(3750 \mathrm{~km})$, and from there to the Laptev Sea $(8600 \mathrm{~km})$, crossing the Eurasian Basin three times (see Fig. 2). (b) Difference between the modeled and the observation-based $\Omega_{\text {arag }}$ for the same transect and time. (c) Modelonly projection of summer $\Omega_{\text {arag }}$ by 2099 under the A2 scenario, and (d) from combining modeled changes in $\Omega_{\text {arag }}$ and observationbased $\Omega_{\text {arag }}$ shown in (a).

enhanced (by about $4 \%$ ). In contrast, the decrease in $\mathrm{pH}$ is about $4 \%$ smaller in the no-warming simulation. This opposite behavior is consistent with the analysis of Cao et al. (2007) for carbon emission scenarios, although they found a weaker effect on $\mathrm{pH}$ than on $\Omega_{\text {arag }}$ in their study with an Earth System Model of Intermediate Complexity. McNeil and Matear (2007) found a climate-change feedback reducing the change in $\Omega_{\text {arag }}$ by about $15 \%$ but almost no feedback on $\mathrm{pH}$; they applied a scenario with prescribed $\mathrm{CO}_{2}$ concen- tration and not a scenario with prescribed carbon emission as done here (see Cao et al., 2007, for differences between emission and concentration scenarios).

Changes in DIC, $\Omega_{\text {arag }}$, and $\mathrm{pH}$ are not linearly related to the atmospheric $\mathrm{CO}_{2}$ increase (Thomas et al., 2007). The Revelle factor defined as the percentage change in $\mathrm{CO}_{2}$ partial pressure divided by the percentage change in DIC increases with increasing $\mathrm{CO}_{2}$ (Revelle and Suess, 1957; Takahashi et al., 1993). Doubling the atmospheric $\mathrm{CO}_{2}$ from 280 to $560 \mathrm{ppm}$ causes global mean surface DIC to increase by $6 \%\left(11 \mathrm{mmol} \mathrm{kg}^{-1}\right)$, whereas increasing $\mathrm{CO}_{2}$ by a further $280 \mathrm{ppm}$ to $840 \mathrm{ppm}$ causes an additional DIC increase of only $3 \%$. Therefore, a higher fraction of the emissions stays in the atmosphere for the high emission A2 scenario than for the low emission B1 scenario. On the other hand, surface mean aragonite saturation decreases by 1.1 unit for a doubling of $\mathrm{CO}_{2}$, but only by 0.5 units for the additional increase from 560 to $840 \mathrm{ppm}$. Similarly, $\mathrm{pH}$ decreases by 0.24 unit for the first $280 \mathrm{ppm}$ increase and by 0.15 unit for the next $280 \mathrm{ppm}$.

\subsection{Regional changes in saturation at the surface}

It is projected that $\Omega_{\text {arag }}$ of surface waters will continue to decrease rapidly in all regions and that high latitude waters will become undersaturated (Figs. 6 and 7). Arctic surface waters are projected to become undersaturated with respect to aragonite within a few decades only, when following business as usual scenarios. Averaged over the entire Arctic, surface annual mean $\Omega_{\text {arag }}$ becomes less than unity in the model when atmospheric $\mathrm{CO}_{2}$ exceeds $490 \mathrm{ppm}(2040 \mathrm{AD}$ in A2 and $2050 \mathrm{AD}$ in B1). The Southern Ocean $\left(65\right.$ to $\left.80^{\circ} \mathrm{S}\right)$ becomes undersaturated on average about 20 years later in the A2 scenario, when atmospheric $\mathrm{CO}_{2}$ concentration exceeds $580 \mathrm{ppm}$, consistent with Orr et al. (2005). By the end of the century, at $840 \mathrm{ppm}$, high latitude surface waters poleward of about $50^{\circ}$ are projected to be undersaturated under the A2 scenario. Depending on the seasonal amplitude, short-time undersaturation during at least one month is reached several years earlier in many regions (Fig. 7b).

The biggest absolute changes in $\Omega_{\text {arag }}$ are found in tropical and subtropical surface waters. In the Tropics $\left(30^{\circ} \mathrm{N}-30^{\circ} \mathrm{S}\right)$ $\Omega_{\text {arag }}$ is projected to drop from 4.2 (1820) to 2.3 in A2. For atmospheric $\mathrm{CO}_{2}$ higher than $585 \mathrm{ppm}$, surface waters will have a zonal mean $\Omega_{\text {arag }}$ of less than three everywhere. These conditions are expected to have significant impacts on the ability of coral reef ecosystems to maintain their structures against the forces of erosion and dissolution (Kleypas et al., 2006).

Turning to the B1 scenario surface changes in $\Omega_{\text {arag }}$ are similar as for the A2 scenario until 2050, as both scenarios follow very similar pathways of atmospheric $\mathrm{CO}_{2}$. After 2050, the more gradual increase of atmospheric $\mathrm{CO}_{2}$ in $\mathrm{B} 1$ slows down the decrease in $\Omega_{\text {arag }}$. By 2100 , undersaturation at the surface is limited to the Arctic Ocean and surface $\Omega_{\text {arag }}$ 

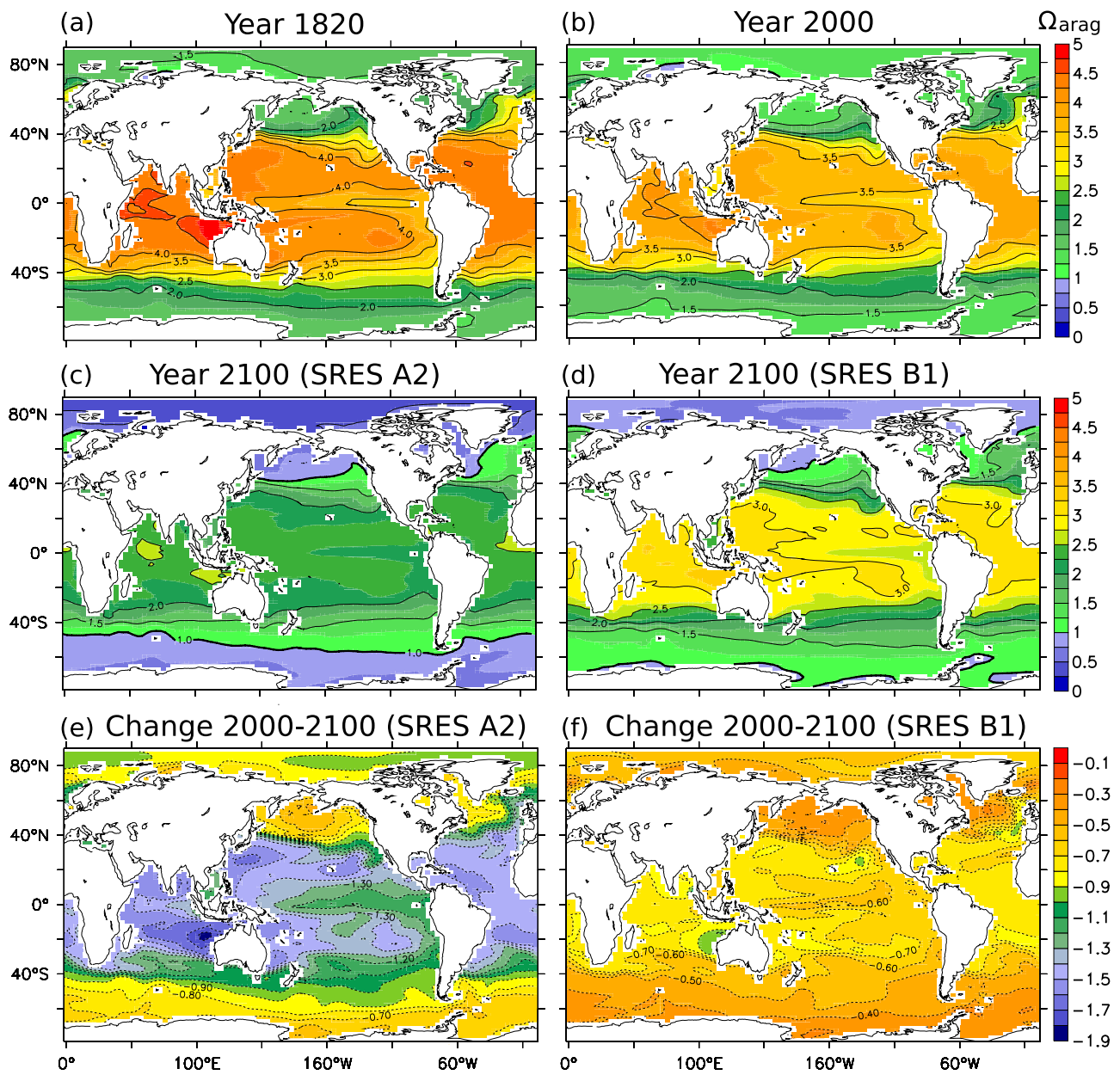

Fig. 6. Simulated aragonite saturation at the surface by the years 1820 (a), 2000 (b), and 2100 (c,d) for SRES scenarios A2 and B1. The largest changes in $\Omega_{\text {arag }}(\mathbf{e}, \mathbf{f})$ are projected for the subtropics.
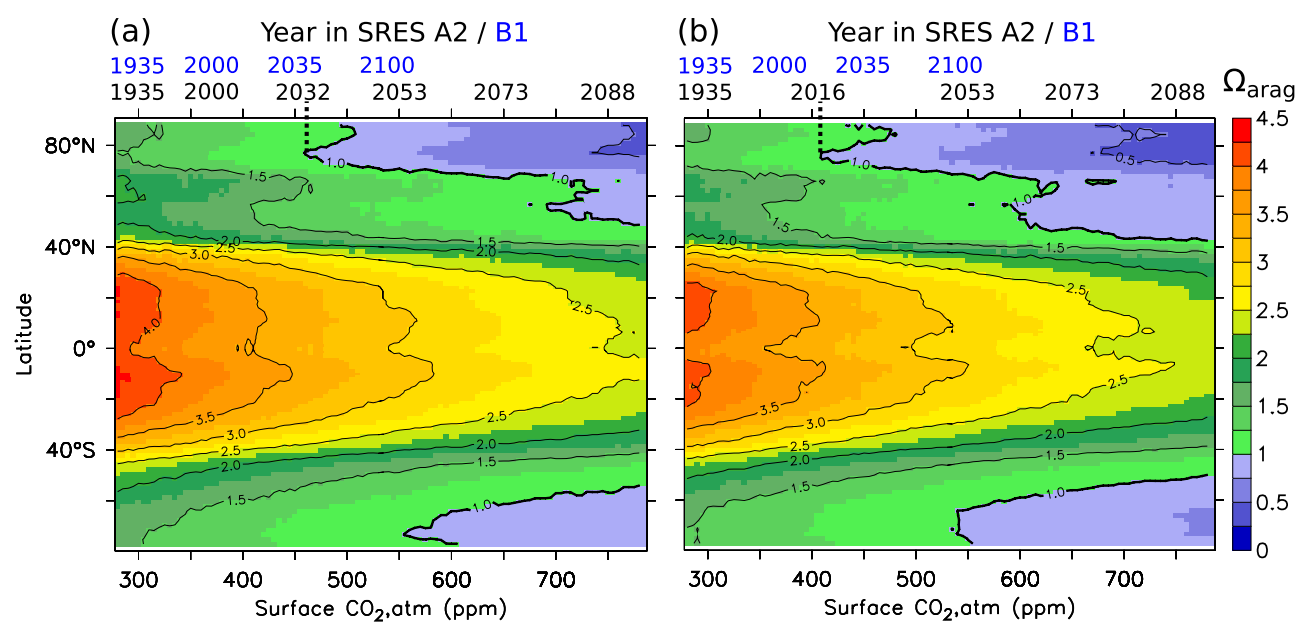

Fig. 7. Projected evolution of the (a) annual-mean and of the (b) lowest monthly mean zonally-averaged aragonite saturation $\Omega_{\text {arag }}$ for the SRES A2 scenario (model only). The evolution is plotted as a function of the annual-mean atmospheric $\mathrm{CO}_{2}$ mixing ratio at the ocean surface. The corresponding years in the $\mathrm{A} 2$ and $\mathrm{B} 1$ scenarios are given at the top. The dotted line indicates the transition from supersaturation to undersaturation in zonal average $\Omega_{\text {arag }}$ at $77^{\circ} \mathrm{N}$ by 2032 and 2016, respectively. 


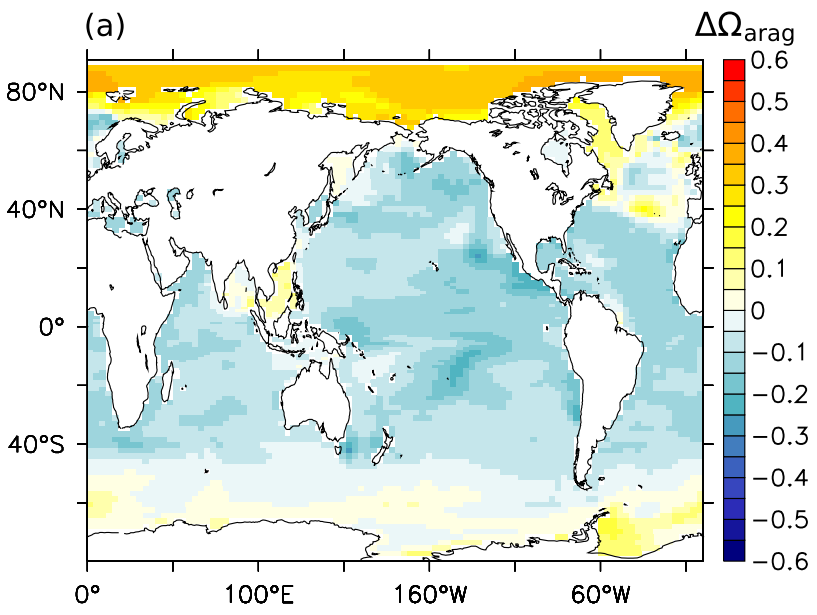

(b)

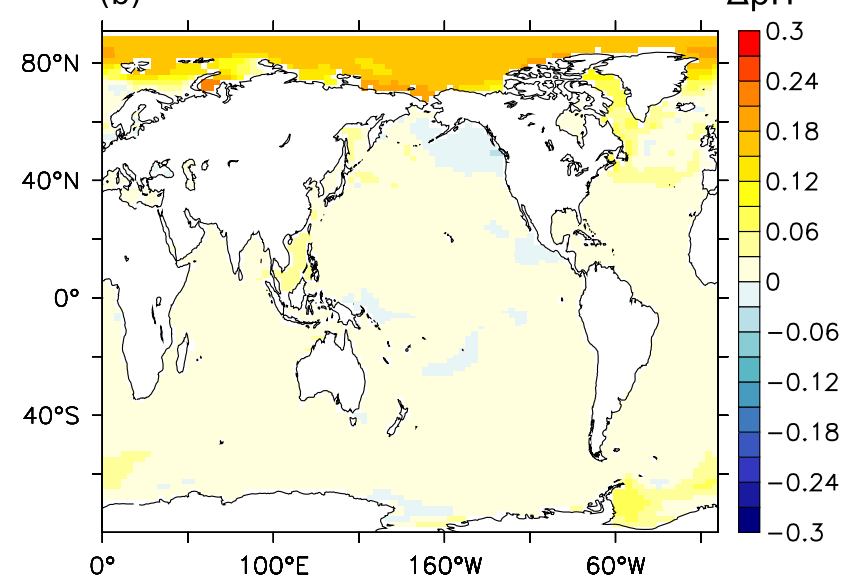

Fig. 8. Differences in projected surface $\Omega_{\text {arag }}$ (a) and $\mathrm{pH}$ (b) between the SRES A2 simulation with and without warming, averaged over the decade 2090-2099. Positive values indicate enhanced acidification by climate change, negative values indicate reduced acidification.

will stabilize at 2.5 to 3.0 in tropical and subtropical regions. The Southern Ocean surface remains slightly supersaturated throughout the B1 simulation.

The climate feedback on $\Omega_{\text {arag }}$ is negative in most regions of the oceans. Exceptions are the Arctic, the Labrador Sea and the high latitude North Atlantic, the Antarctic polar zone and a few coastal regions (Fig. 8). The modeled high latitude changes are linked to sea ice as discussed for the Arctic; we note that the model simulates too much sea ice in the North Atlantic and North Pacific (Weatherly et al., 1998) and the magnitude of the positive feedback in the high latitude North Atlantic may not be realistic. The climate feedback on $\mathrm{pH}$ is positive (or only slightly negative) in all regions.

\subsection{Changes at depth and in the volume of supersatu- rated waters}

Saturation is decreasing not only at the surface but also in the thermocline and the deep ocean as anthropogenic carbon continues to invade the ocean. This is illustrated by Hovmöller diagrams of $\Delta\left[\mathrm{CO}_{3}^{2-}\right]$ for selected regions (Fig. 9). The thermocline changes in $\left[\mathrm{CO}_{3}^{2-}\right]$ are relatively modest over the past 200 years. However, the modeled $\mathrm{CO}_{3}^{2-}$ concentrations decrease rapidly over this century and the saturation horizon, separating over- and undersaturated waters, shoals in most regions.

For the A2 scenario and over this century, the anthropogenic perturbation is projected to penetrate the top $3500 \mathrm{~m}$ in the North Atlantic, leading to a shoaling of the saturation horizon from $3250 \mathrm{~m}$ to $1300 \mathrm{~m}$ in mid and high latitudes and an extension of the undersaturated water masses in the low latitude Atlantic thermocline. In the Arctic and in the Southern Ocean supersaturation is already small today and the top 300 and $400 \mathrm{~m}$ will become undersatured over the coming decades in the A2 scenario (Fig. 9). In the tropical Pacific the anthropogenic perturbation extends down to the depth of about $1000 \mathrm{~m}$ and the saturation horizon remains at $1500 \mathrm{~m}$.

The anthropogenic perturbation causes a substantial loss of habitat for calcifying organisms. We introduce five classes of saturation levels: (i) more than $400 \%$ saturated $\left(\Omega_{\mathrm{arag}}>4\right)$ as considered optimal for coral growth, (ii) 300 to $400 \%$ saturated, considered as adequate for coral growth, (iii) 200 to $300 \%$ saturated and (iv) 100 to $200 \%$ saturated, both considered as marginal to inadequate for coral growth (Langdon and Atkinson, 2005; Kleypas et al., 2006), and finally (v) undersaturated water $\left(\Omega_{\mathrm{arag}}<1\right)$ considered to be unsuitable for pteropods (Feely et al., 2004; Orr et al., 2005). The volume of water that is more than $400 \%$ saturated is projected to vanish in the next three decades for the A2 and B1 scenario (Fig. 10). Water with $\Omega_{\text {arag }}$ larger than three is projected to vanish by $2070\left(\mathrm{CO}_{2} \approx 630 \mathrm{ppm}\right)$ in the $\mathrm{A} 2$ scenario and to be reduced to $11 \%$ of the respective preindustrial volume in the B1 scenario. Further, the volumes of waters with $2<\Omega_{\text {arag }}<3$ and $1<\Omega_{\text {arag }}<2$ are projected to decrease by about $75 \%$ and $30 \%$ over the industrial period and this century for the A2 scenario; corresponding changes are about half as large for B1 than for A2.

Overall the volume occupied by water oversaturated with respect to aragonite decreases from about $42 \%$ to $25 \%$ of the total ocean volume. We note that the model correctly simulates the total volume occupied by the first three classes, whereas the volume with an aragonite saturation between 100 and 200\% is overestimated (crosses in Fig. 10). Therefore, these projections might be somewhat too optimistic.

\subsection{Changes in the Arctic Ocean and climate feedbacks}

Our projection that the Arctic ocean will become undersaturated with respect to aragonite in a few decades calls for a 
(a) Atlantic Ocean $\left(65^{\circ} \mathrm{N}-35^{\circ} \mathrm{S}\right)$

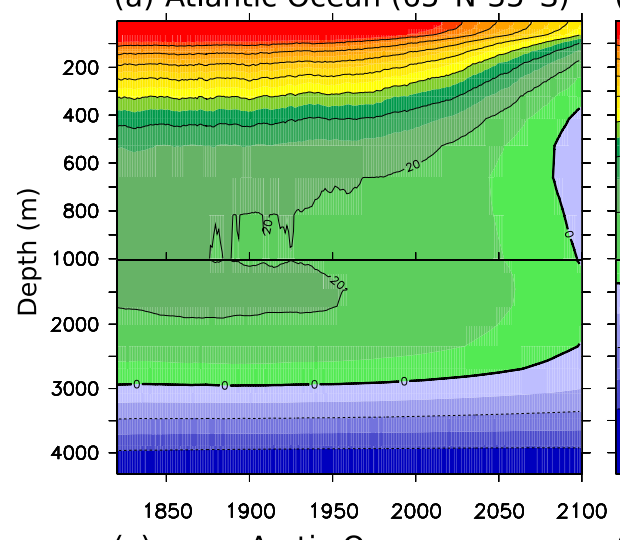

(c)

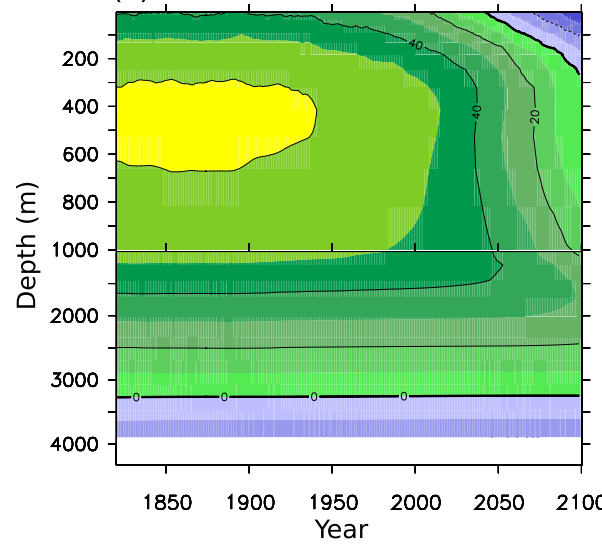

(b) Pacific Ocean $\left(65^{\circ} \mathrm{N}-35^{\circ} \mathrm{S}\right)$

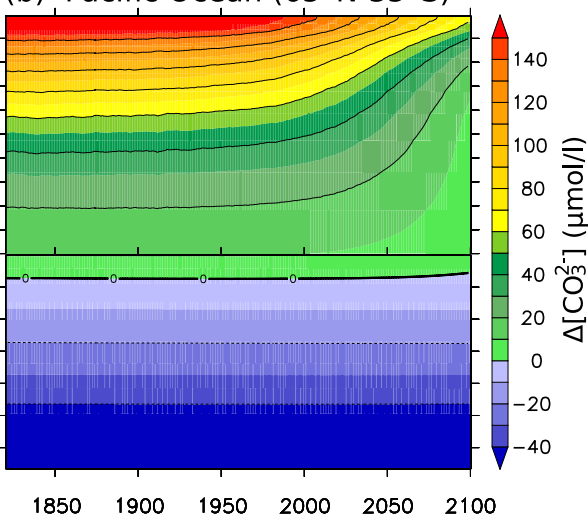

(d) Southern Ocean $\left(50-70^{\circ} \mathrm{S}\right)$

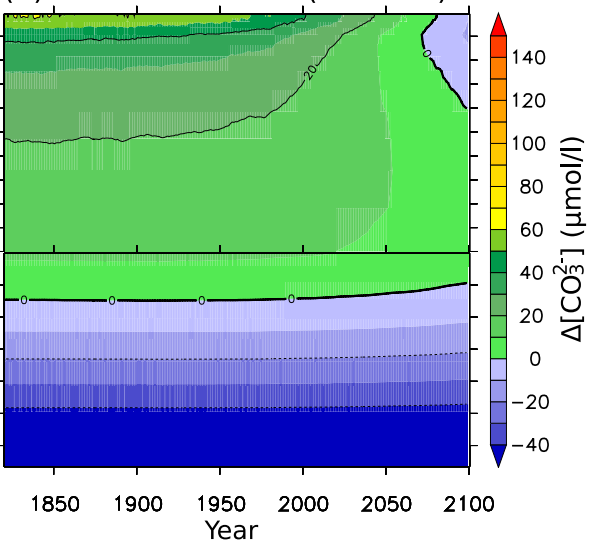

Fig. 9. Time-depth diagrams of simulated annual mean $\Delta\left[\mathrm{CO}_{3}^{2-}\right](\mu \mathrm{mol} / \mathrm{l})$ with respect to aragonite for SRES A2; in the (a) Atlantic, (b) Pacific (c) Arctic, and (d) in the Southern Ocean.

more detailed analysis. We combine observation-based estimates of $\Omega_{\text {arag }}$ with the modeled changes to obtain an alternative estimate of the saturation state in the Arctic in 2100: $\Omega(t)=\Omega_{\text {obs. }}\left(t_{0}\right)+\Omega_{\text {model }}(t)-\Omega_{\text {model }}\left(t_{0}\right)$. In this way, $\Omega_{\text {arag }}$ is adjusted for known model biases similar to the approach of Orr et al. (2005), who applied simulated changes in DIC to observation-based estimates. The difference between adjusting $\Omega$ directly and calculating $\Omega$ from adjusted DIC and Alk concentrations is small $(<1 \%)$. In 2100 and for A2, the entire water column is projected to be undersaturated except some small regions at depths between $1000 \mathrm{~m}$ and $2000 \mathrm{~m}$ (Fig. 5). For comparison, the model-only projection also shows a distinct undersaturation in the top few hundred meters $\left(\Omega_{\text {arag }}\right.$ between 0.25 and 0.75 ), whereas water remains oversaturated between 1000 and $3500 \mathrm{~m}$ in the model only projection as the modeled $\mathrm{CO}_{3}^{2-}$ concentration is biased high. In any case, the emerging undersaturation of the surface Arctic ocean is a robust feature and independent of these model biases.

Undersaturation occurs first in small regions and over short periods of the year. Its spatial and seasonal occurrence increases with rising atmospheric $\mathrm{CO}_{2}$ as summarized in Table 1 for the investigated Arctic transect and for the model-data approach. $10 \%$ of the surface area is projected to become undersaturated with respect to aragonite in at least one month of the year when atmospheric $\mathrm{CO}_{2}$ has reached $409 \mathrm{ppm}$ at year 2016 in the A2 and at year 2018 in the B1 scenario. At 428 ppm (2023 AD in A2, 2025 AD in B1) $10 \%$ of the surface is projected to become undersaturated in the annual mean, and at $450 \mathrm{ppm}$ (2029 AD in A2, $2034 \mathrm{AD}$ in B1) throughout the year. More than $50 \%$ of the surface waters of that section will become undersaturated at $\mathrm{CO}_{2}$ levels of $534 \mathrm{ppm}(2050 \mathrm{AD}$ in $\mathrm{A} 2,2085 \mathrm{AD}$ in $\mathrm{B} 1)$, and at $765 \mathrm{ppm}$ (2090 AD in A2) the entire water column is projected to become undersaturated.

The largest $\mathrm{pH}$ changes over the 21 th century $(-0.45$ in A2, -0.23 in B1) are simulated in the Arctic Ocean. This turns the Arctic Ocean from a region with relatively high $\mathrm{pH}$ (0.06 units above the global average) to a region with very low $\mathrm{pH}(0.09$ units below the global average by 2100 in A2). $\left[\mathrm{H}^{+}\right]$increases from $7.3 \mathrm{nmol} / 1$ to $20.8 \mathrm{nmol} / 1$ in $\mathrm{A} 2$ and to $12.35 \mathrm{nmol} / \mathrm{l}$ in $\mathrm{B} 1$, respectively.

Next the role of climate change and of different processes for the projected Arctic changes is addressed. Warming in the Arctic region is much higher than on global average 

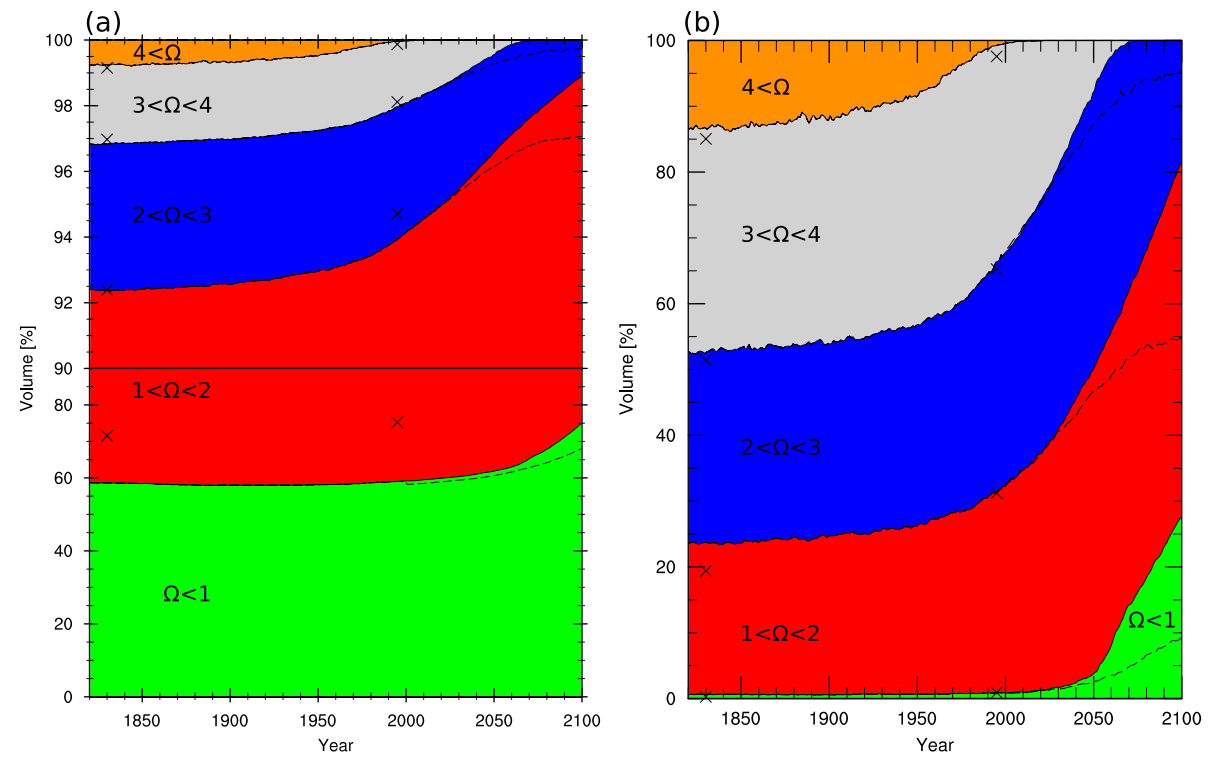

Fig. 10. Simulated global changes in the volume of supersaturated waters with respect to aragonite under the SRES A2. Panel (a) shows changes in the entire ocean volume, whereas panel (b) shows only changes for the top $200 \mathrm{~m}$. Waters that are more than four times supersaturated (orange) are projected to vanish by the year 2010, and those that are 3 to 4 times supersaturated (gray) by the year 2070. The volumes of 2-3 and 1-2 times supersaturated waters (blue and red) decrease to $25 \%$ and $70 \%$ with respect to the preindustrial values by 2100 . Thus the volume of undersaturated waters (green) increases by about $30 \%$ (or $17 \%$ of the total ocean volume) by 2100 . The dashed lines indicate the volume changes under the SRES B1 scenario. The crosses denote the respective values derived from the GLODAP/WOA01 data set for 1995 and the estimated preindustrial values (1830) obtained by subtracting estimated anthropogenic $\mathrm{CO}_{2}$ from DIC concentrations.

(polar amplification) and summer sea ice cover is projected to be significantly reduced. The Arctic Ocean is projected to become fresher in response to sea ice melt, altered evaporation and precipitation, and river input. Small climate feedbacks on $\Omega_{\text {arag }}$ and $\mathrm{pH}$ have been reported for the global ocean. However, climate change amplifies the decrease in average annual mean Arctic surface $\Omega_{\mathrm{arag}}$ and $\mathrm{pH}$ by $22 \%$ and $27 \%$, respectively (Fig. 8). In the simulation without global warming, alkalinity remains roughly constant in the Arctic, while the dissolved inorganic carbon concentration increases as a result of anthropogenic carbon uptake. Both surface Alk and DIC decrease in the simulation with global warming (Fig. 11). Additional freshwater input into the Arctic Ocean dilutes the tracer concentrations. The simulated decrease in DIC is smaller than that for Alk, mainly because the uptake of anthropogenic carbon tends to increase DIC. Overall, the difference between Alk and DIC, governing the $\mathrm{CO}_{3}^{2-}$ concentration, decreases more in the standard global warming simulation than in the simulation without climate change, thereby amplifying the changes in saturation state.

We can quantitatively attribute the changes of Alk and DIC, and thus $\left[\mathrm{CO}_{3}^{2-}\right]$, to different mechanisms. A budget of the Alk and DIC fluxes entering and leaving the Arctic surface ocean (top 200 m) is established (Fig. 12) for the A2 scenario. The changes in the difference between Alk and DIC is taken as a proxy for changes in the $\mathrm{CO}_{3}^{2-}$ concen- tration. This approximation works well in the Arctic surface ocean (inset of Fig. 12). We note that the regression slope is slightly different in the no-warming simulation $(0.43$, $\left.r^{2}=0.94\right)$ than in the standard global warming simulation $\left(0.38, r^{2}=0.90\right)$. In the no-warming simulation, the freshwater balance, ocean circulation, the marine biological cycle and Alk remain mostly unperturbed. We note a small perturbation of the global hydrologic cycle, which arises most likely due to the interaction of increasing atmospheric $\mathrm{CO}_{2}$ with the terrestrial biosphere. However, the most relevant changes are the uptake of anthropogenic (excess) carbon by gas exchange through the air-sea interface and the export of excess carbon out of the top $200 \mathrm{~m}$ by surface-to-deep and lateral (to the North Atlantic and through the Bering Strait) exchange. The resulting storage of anthropogenic carbon in the top $200 \mathrm{~m}$ increases DIC and decreases (Alk-DIC) by $0.10 \mathrm{mmol} / \mathrm{l}$ by 2100 . In the standard global warming simulation, additional freshwater input dilutes both Alk and DIC. The decrease in Alk and DIC by freshwater input is proportional to their concentration and thus larger for Alk than for DIC. As a result, (Alk-DIC) is reduced by $0.035 \mathrm{mmol} / \mathrm{l}$ on average. The dilution of DIC by freshwater lowers the $\mathrm{CO}_{2}$ partial pressure which in combination with an increase in ice-free area enhances uptake of anthropogenic carbon through gas exchange. Increased uptake is further promoted by the somewhat higher atmospheric $\mathrm{CO}_{2}$ concentration in 


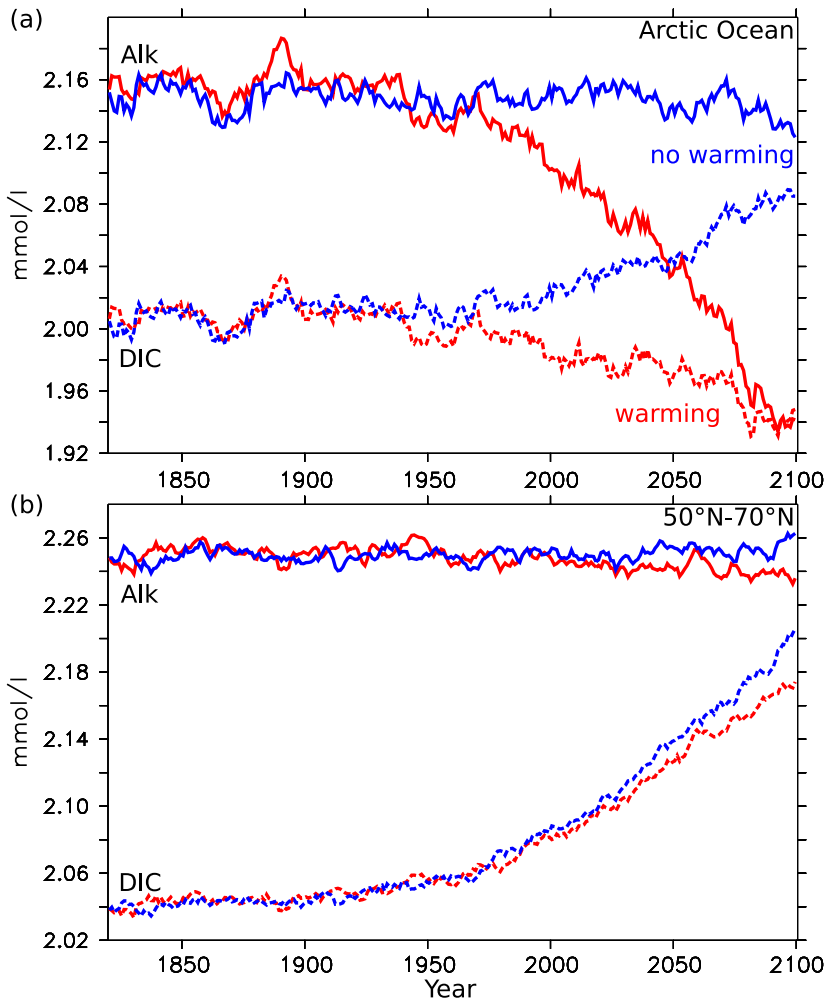

Fig. 11. Simulated annual mean alkalinity and DIC surface concentrations from 1820 to 2100 in the Arctic Ocean (a) and between $50^{\circ} \mathrm{N}$ and $70^{\circ} \mathrm{N}(\mathbf{b})$. Without warming (blue) both regions show similar changes. Including climate change (red) changes alkalinity and DIC in the North Pacific and North Atlantic only slightly and the difference Alk-DIC, which is approx. proportional to $\left[\mathrm{CO}_{3}^{2-}\right]$, is almost constant. This is representative for all regions, except the Arctic, where the alkalinity is strongly reduced and the difference Alk-DIC is virtually zero by the end of the 21 th century.

the warming than in the no-warming simulation. On the other hand the dilution of Alk increases the $\mathrm{CO}_{2}$ partial pressure, which tends to decrease the uptake of anthropogenic carbon. The net effect is an increase in $\mathrm{CO}_{2}$ uptake by about $40 \%$ in the warming simulation relative to the no-warming simulation. The export of excess carbon out of the top $200 \mathrm{~m}$ by physical transport is also enhanced in the warming simulation. Further, the projected changes in environmental conditions enhance marine biological productivity and the export of organic material and $\mathrm{CaCO}_{3}$ out of the Arctic surface. As a result, surface (Alk-DIC) is increased by $0.013 \mathrm{mmol} / \mathrm{l}$. Thus, the biological feedbacks partly counter the physicallydriven climate feedback. Considering all fluxes, (Alk-DIC) decreases by $0.036 \mathrm{mmol} / 1(38 \%)$ more in the warming than in the no-warming simulation. This may be compared to a $0.013 \mathrm{mmol} / \mathrm{l}(34 \%)$ higher decrease in $\left[\mathrm{CO}_{3}^{2-}\right]$.

Freshwater input at the ocean surface in the Arctic is increased due to melting of sea ice, as well as increased precip-

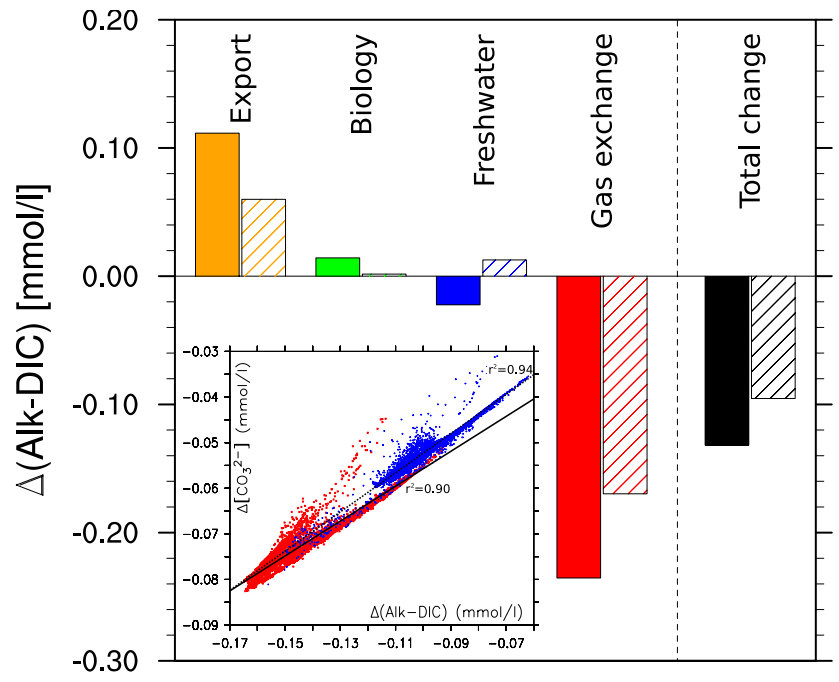

Fig. 12. Projected changes in the annual mean difference Alk-DIC, which is approximately proportional to $\left[\mathrm{CO}_{3}^{2-}\right]$, from 1820 to 2100 under the A2 scenario in the top $200 \mathrm{~m}$ of the Arctic Ocean. The total change (black) is composed of changes in the net $\mathrm{CO}_{2}$ uptake by gas-exchange with the atmosphere (red), changes in the freshwater flux at the ocean surface (blue), as well as changes in biology (green) and in the export of excess carbon by surface-to-deep and lateral exchange (orange). The difference between the simulation without warming (hatched) and the standard global warming simulation (solid) quantifies the impact of climate change on the individual components and on the total amplification of the carbonate ion reduction. The inset relates the changes in the difference AlkDIC to the changes in $\left[\mathrm{CO}_{3}^{2-}\right]$ for all grid boxes that contribute to the Arctic budget and for the warming (red) and no-warming (blue) simulations. The strong correlation indicates that the difference Alk-DIC is a reasonable proxy for $\left[\mathrm{CO}_{3}^{2-}\right]$ in the Arctic surface ocean.

itation and reduced evaporation. In the CSM 1.4, rivers deliver pure freshwater to the ocean, with DIC and alkalinity set to zero. Land-ice is absent from the simulations. The annual mean sea ice volume in the Arctic Ocean is reduced by $69 \%$ in the A2 simulation from $3.48 \times 10^{4} \mathrm{~km}^{3}$ (preindustrial) to $1.07 \times 10^{4} \mathrm{~km}^{3}$ (2100). The summer sea ice cover is reduced by $74 \%$ from $8.7 \times 10^{6} \mathrm{~km}^{2}$ (preindustrial) to $2.3 \times 10^{6} \mathrm{~km}^{2}$ (2100), which corresponds to a cover of $88 \%$ and $23 \%$ of the total Arctic Ocean surface $\left(9.9 \times 10^{6} \mathrm{~km}^{2}\right)$, respectively. The reduced sea ice cover allows gas exchange to occur in a larger area and the availability of light is increased in the ocean surface layer. The summer sea ice extent in the CSM is $10-40 \%$ higher than observed by 2000 (Fig. 13). The reduction in sea ice cover is at the lower end of the range of projections for the 21 th century. More specifically, the simulated decrease from 2000 to 2100 in the A2 scenario is only slightly larger than the rapid reduction observed during the last decade. Holland et al. (2006) project abrupt reduction in summer Arctic sea ice and near ice-free conditions by 2040 


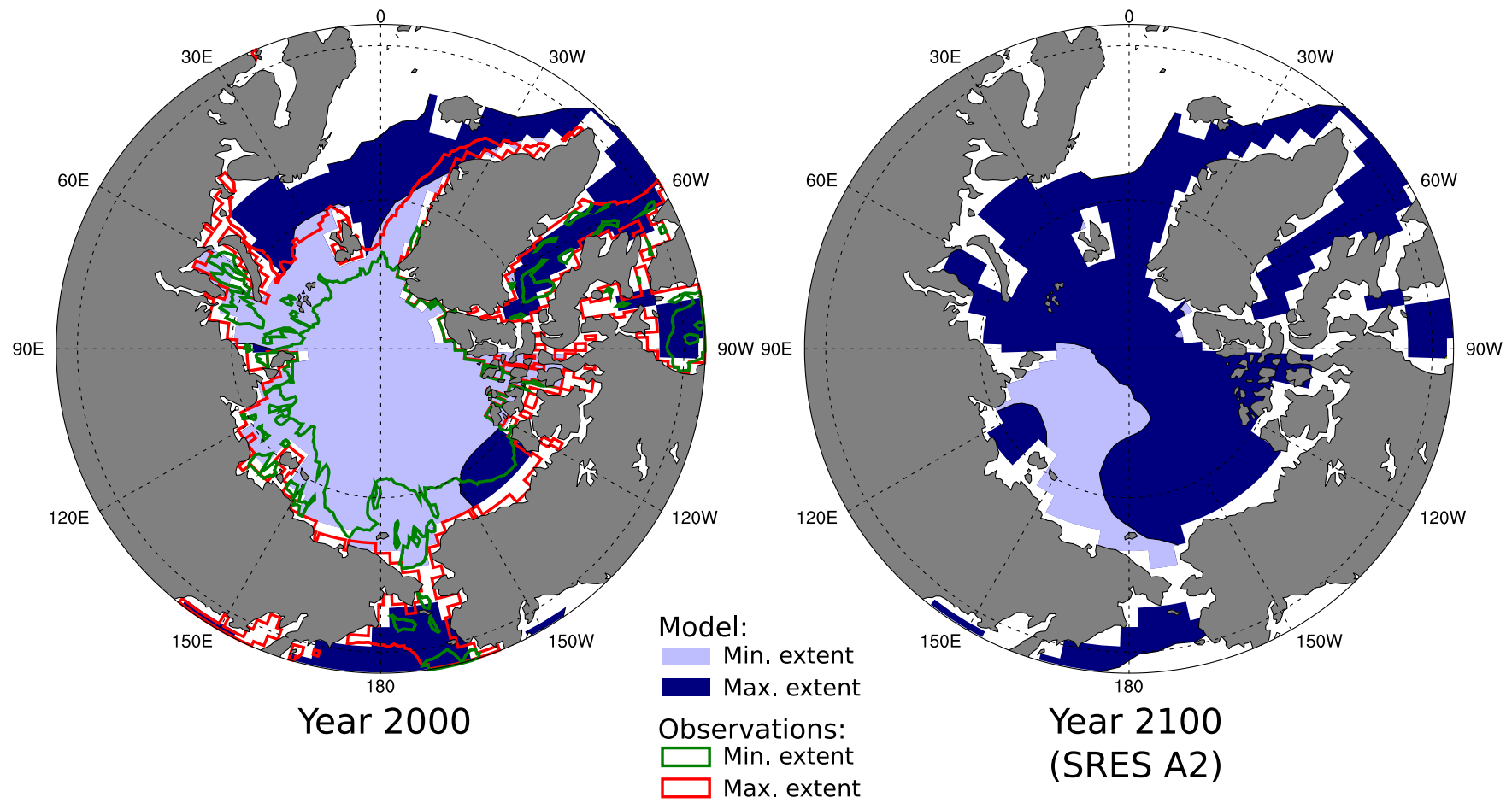

Fig. 13. Sea ice cover in the Arctic Ocean by the years 2000 and 2100. The color shading shows simulated minimum (light blue) and maximum (dark blue) sea ice extent. Lines indicate minimum (green) and maximum (red) sea ice extent as observed in the year 2000 (Walsh, 1978). The sea ice extent is defined here as the area where the sea ice concentration is above $50 \%$.

for the SRES A1B scenario, whereas in our SRES A2 simulation summer sea ice cover remains above $70 \%$ of the total Arctic Ocean surface until about 2050. The simulated winter ice cover declines only little and remains larger than the observed present-day ice cover throughout the simulation. If the projections of rapid summer sea ice decline are true, the projected effects we see on the Arctic carbonate system will be even more pronounced than seen in the CSM simulations. Freshwater input and warming also cause an increase in stratification, here defined by the density difference between the surface and $200 \mathrm{~m}$ depth.

Modelled marine biological production in the Arctic increases due to a number of factors (Steinacher, 2007). Most importantly, enhanced availability of photosynthetic active radiation in response to reduced sea ice cover (and changes in cloud cover) and ocean surface warming stimulate productivity. Simulated shortwave irradiance increases by $200 \%$ at the air-water interface and sea surface temperature increases by $0.31^{\circ} \mathrm{C}$ in scenario $\mathrm{A} 2$ by 2100 . On the other hand, iron and phosphate concentration decrease only by a few percent. We note that production is limited by temperature and light, but not by phosphate and iron. The averaged mixed layer depth remains roughly unchanged.

\subsection{Seasonal and interannual variability of $\Omega_{\mathrm{arag}}$}

The simulated seasonal and interannual variability of $\Omega_{\text {arag }}$ is small compared to the projected anthropogenic changes discussed above. The zonal mean seasonal cycle of $\Omega_{\text {arag }}$ shows the typical quadrupole space-time pattern (Fig. 14a, b) with largest positive seasonal deviations in summer and largest negative deviations in winter in both hemispheres and at midlatitudes. This seasonal cycle is driven by low summer DIC and high winter DIC values linked to thermally driven airsea exchange and nutrient drawdown during the spring and summer growing season, as well as winter convection and mixing. The seasonal variability of simulated $\Omega_{\text {arag }}$ is small in the high latitude and in the tropical surface ocean $( \pm 0.1$ in zonal mean $\Omega_{\text {arag }}$; less than 5\%). In Northern Hemisphere mid-latitudes deviations up to $15-20 \%(0.35-0.40$ in zonal mean $\Omega_{\text {arag }}$ ) can be found, with maximum values from $\mathrm{Au}-$ gust to October and minimum values from February to April (Fig. 14). Largest seasonal amplitudes ( $\Delta \Omega_{\mathrm{arag}}$ up to 0.7 ) can be found around $40^{\circ} \mathrm{N}$ in the western Pacific and Atlantic, as well as in the South Atlantic near the coast of Argentina. These regions correspond to regions of high primary productivity and large seasonality in production. Surface $\Omega_{\text {arag }}$ is increased at the end and after the high production phase, when nutrient and DIC concentrations are reduced. 

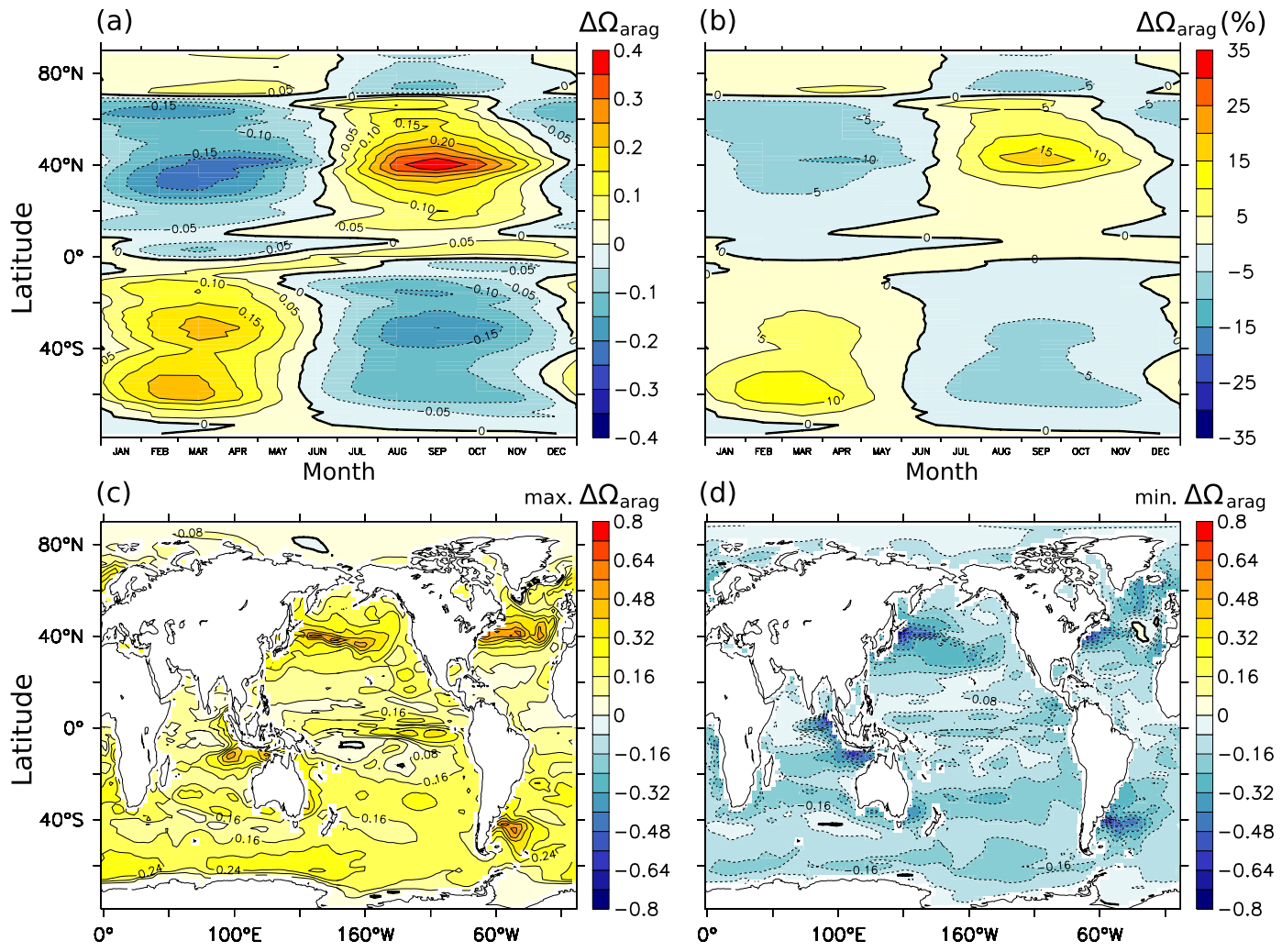

(e)
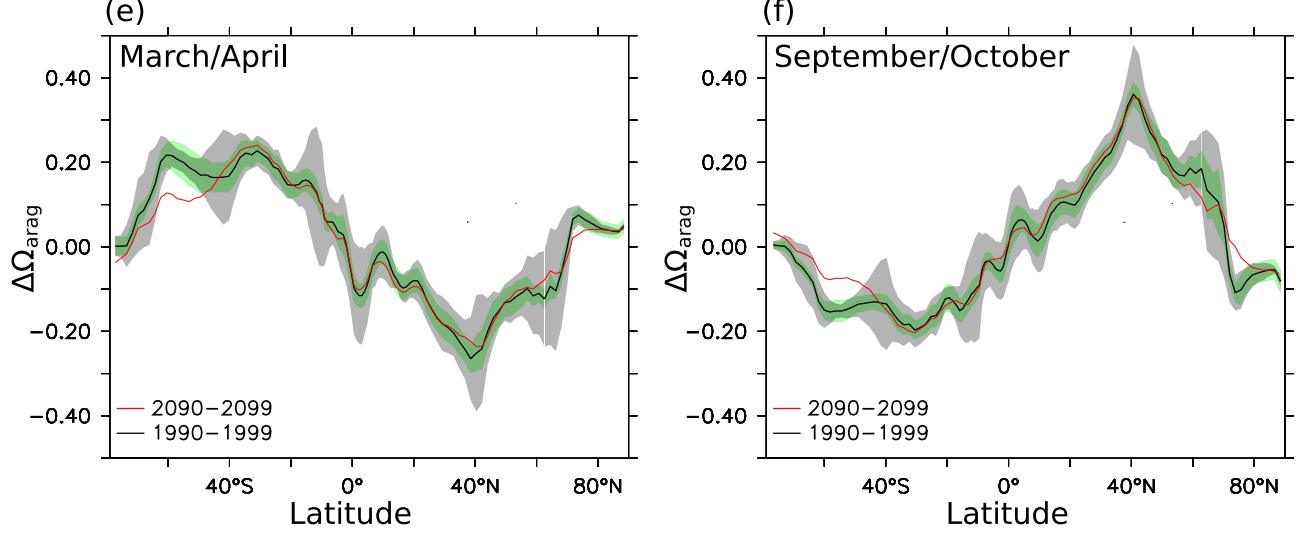

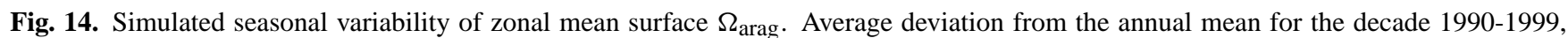
in absolute values (a) and relative to the annual mean $\Omega_{\text {arag }}(\mathbf{b}$, in percent). Maps of maximum positive (c) and negative (d) anomalies in surface $\Omega_{\text {arag }}$ for the decade 1990-1999 (maximum deviation from the decadal mean at each grid point and for every month). Average deviation from the annual mean in March/April (e) and September/October (f) for the decades 1990-1999 (black line) and 2090-2099 (red line) under SRES A2. The shaded areas indicate the interannual variability (green, $\pm \sigma$ ) and the variability across different longitudes (grey, $\pm \sigma$ ) for the decade 1990-1999.

The seasonal variability in the Arctic Ocean is out of phase with the general Northern Hemisphere seasonal signal and shows the same seasonal pattern as modeled for the Southern Hemisphere. Melting of Arctic sea ice decreases the supersaturation over the summer. The variability in sea ice cover and the associated freshwater input lead to a strong seasonal variability of alkalinity (up to $\pm 4 \%$ ) and DIC, which outbal- ances the relatively small variability in temperature. Overall, seasonal variability in $\Omega_{\text {arag }}$ is small $(<0.1)$ compared to the simulated anthropogenic changes in the Arctic.

The modeled large scale amplitudes and patterns of the seasonal variability do not show significant changes between 1820 and 2100 in the transient simulation under the A2 scenario in most regions. In the Southern Ocean (south of $40^{\circ} \mathrm{S}$ ) 
and around $50^{\circ} \mathrm{N}$ and $75^{\circ} \mathrm{N}$ the seasonal amplitude tends to be slightly reduced (Fig. 14). However, as the annual mean $\Omega_{\text {arag }}$ decreases with increasing $\mathrm{CO}_{2}$, the relative seasonal variability increases from about $+10 \% /-5 \%$ at $40^{\circ} \mathrm{N}$ in 1820 to about $+25 \% /-15 \%$ in 2100 . Finally, we note that the interannual variability in zonal mean $\Omega$ is small (less than \pm 0.1 in surface $\Omega_{\mathrm{arag}}$ ) both compared to the anthropogenic change as well as compared to zonal variability (Fig. 14). Because calcification is linearly coupled with production in the CSM1.4, interannual variability that could be caused by variations in the $\mathrm{CaCO}_{3}$ /organic carbon formation and remineralization rates is not captured by the model.

\section{Discussion and conclusions}

The changes in the acid-base state of ocean waters in response to human induced carbon emissions have been analyzed with the NCAR CSM1.4-carbon coupled climatecarbon cycle model for two transient greenhouse gas emission scenarios. The model is able to reproduce the largescale, contemporary distribution of carbonate and the saturation state with respect to aragonite reasonably well. A number of caveats are nevertheless worth mentioning. Results simulated for the North Pacific should be viewed with caution as the model overestimates saturation in this basin. The NCAR CSM1.4 model has a climate sensitivity near the lower bound of current estimates and simulated magnitudes of climate feedbacks on changes in saturation and $\mathrm{pH}$ might be somewhat low. However, these feedbacks play a minor role in most regions. Further, the model does not distinguish between different mineral phases (calcite, aragonite, high-Mg calcite) of calcium carbonate (Gangst $\varnothing$ et al., 2008) and therefore has a single length-scale for calcium carbonate remineralization independent of seawater saturation state. The model does not include an active sediment reservoir or sediment burial and further research is needed to quantify the magnitude of a potential buffering of the simulated changes in saturation by re-dissolution of calcium carbonate from ocean sediments. Langdon (2002) suggests that dissolution rates on reefs, banks, and tropical shelves will not be able to buffer the $\left[\mathrm{CO}_{3}^{2-}\right]$ decrease over the next $50-100$ years.

Our study with a coupled climate-carbon cycle model supports the important finding of earlier studies that the acidbase state of the global ocean is currently undergoing large and rapid changes (Orr et al., 2005; Caldeira and Wickett, 2003) in response to anthropogenic carbon emissions with potentially large negative socio-economic impacts (HoeghGuldberg, 2005). The saturation state with respect to aragonite, calcite, or high-magnesium calcite is decreasing worldwide, causing a gradual worsening of living conditions for corals, pteropods, foraminiferas and coccolitophorides and potentially also for non-calcifying marine organisms (e.g. Fabry et al., 2008). Orr et al. (2005) have pointed out that the
Southern Ocean will become undersaturated for aragonite if atmospheric $\mathrm{CO}_{2}$ increases beyond $560 \mathrm{ppm}$.

We highlight that the Arctic Ocean surface becomes undersaturated with respect to aragonite at even lower $\mathrm{CO}_{2}$ concentration. The combination of observation-based estimates of $\Omega_{\text {arag }}$ in the Arctic (Jutterström and Anderson, 2005) with NCAR CSM1.4-carbon model projection indicates that $10 \%$ of the surface water along the investigated Arctic transect will become undersatured for at least one month of the year when atmospheric $\mathrm{CO}_{2}$ exceeds $409 \mathrm{ppm}$. This concentration is only $25 \mathrm{ppm}$ higher than today's value and projected to be reached within the next decade for all SRES scenarios (Plattner et al., 2008; Meehl et al., 2007) and within the next two decades for the recent set of multi-gas mitigation scenarios (Van Vuuren et al., 2008; Strassmann et al., 2008). The entire water column in the Arctic is projected to become undersaturated within this century if anthropogenic carbon emissions continue to grow along the SRES A2 business-asusual trajectory. Even under the relatively low- $\mathrm{CO}_{2}$ scenario B1, more than $50 \%$ of the Arctic surface waters are projected to become undersaturated. These results are consistent with the study by (Orr et al., 2008) who analyzed Arctic acidification based on results from different AOGCMS, including the NCAR CSM1.4-carbon.

Atmospheric $\mathrm{CO}_{2}$ will very likely exceed $400 \mathrm{ppm}$ in the next one or two decades given current carbon emission trends and the inertia of the energy and the whole socio-economic system. The question is thus not whether undersaturation will occur in the Arctic, but how big its magnitude will be, how large an area will be affected by undersaturation, and over how many months of the year undersaturation will be prevalent. Our findings, combined with the emerging evidence on the impacts of aragonite undersaturation on marine organisms imply that not only radiative forcing or temperature, but also atmospheric $\mathrm{CO}_{2}$ concentration should be included as a target in climate policy analyses and in the development of mitigation scenarios with integrated assessment models. Our subjective assessment is that atmospheric $\mathrm{CO}_{2}$ should not exceed $450 \mathrm{ppm}$ in order to avoid the risk of large changes in marine ecosystems.

The loss in volume of water with saturation has been quantified. We consider five saturation regimes for ease of discussion. Water with an aragonite saturation of more than $300 \%$, considered suitable for coral growth, are projected to vanish completely in the second half of the century for the A2 scenario. Water with a saturation of more than $400 \%$, considered optimal for coral growth, covered about $16 \%$ of the surface at preindustrial time and will be gone in the next few years. Overall, the volume of water supersaturated with respect to aragonite decreases strongly in the A2 and B1 scenarios considered here, with potentially adverse effect also on species living on the ocean floor and in the deep (Guinotte et al., 2006).

Our analysis shows that in addition to the uptake of anthropogenic carbon by air-sea gas exchange, freshwater input 
from increased precipitation and ice melt contributes to the decrease in Arctic saturation state, while an increase in marine biological production slightly counteracts the decline. Additional freshwater input from land ice melt has not been considered here and is expected to sligthly lower projected saturation states (Orr et al., 2008). Seasonal variability in saturation is significant in mid-latitudes regions, but small at high latitudes. The anthropogenic changes in saturation are superimposed on the seasonal variations. We did not find substantial changes in seasonal variability over this century in the NCAR model. Interannual variability in saturation is found to be small. These findings are consistent with results obtained at time series stations (HOT, BATS), which show that the anthropogenic signal is clearly distinguishable from seasonal and interannual variability (Bates, 2001; Brix et al., 2004; Kleypas et al., 2006).

In conclusion, human activities are perturbing the ocean and the habitats for marine organisms. The results of this study and of Feely et al. (2008) for the coastal North Pacific and Orr et al. (2008) for the Arctic show that undersaturation of surface waters with respect to aragonite is likely to become reality in a few years only.

Acknowledgements. This work was funded by the European Union projects CARBOOCEAN (511176-2) and EUROCEANS (511106-2) and is a contribution to the "European Project on Ocean Acidification" (EPOCA) which received funding from the European Community's Seventh Framework Programme (FP7/2007-2013) under grant agreement no. 211384. Additional support was received from the Swiss National Science Foundation and SCD acknowledges support from the US National Science Foundation (NSF) grant ATM-0628582. Simulations were carried out at the Swiss National Supercomputing Centre (CSCS) in Manno, Switzerland.

Edited by: C. Heinze

\section{References}

Ammann, C. M., Joos, F., Schimel, D. S., Otto-Bliesner, B. L., and Tomas, R. A.: Solar influence on climate during the past millennium: Results from transient simulations with the NCAR Climate System Model, P. Natl. Acad. Sci. USA, 104, 3713-3718, doi:10.1073/pnas.0605064, 2007.

Anderson, L. A. and Sarmiento, J. L.: Redfield ratios of remineralization determined by nutrient data analysis, Global Biogeochem. Cy., 8, 65-80, 1994.

Bates, N. R.: Interannual variability of oceanic $\mathrm{CO}_{2}$ and biogeochemical properties in the Western North Atlantic subtropical gyre, Deep-Sea Res. Pt. II, 48, 1507-1528, 2001.

Bettge, T. W., Weatherly, J. W., Washington, W. M., Pollard, D., Briegleb, B. P., and Strand, W. G.: The CSM Sea Ice Model, NCAR Tech. Note NCAR/TN-425+STR, National Center for Atmospheric Research, Boulder, Colorado, USA, 1996.

Bonan, G. B.: The NCAR Land Surface Model (LSM version 1.0) coupled to the NCAR Community Climate Model, NCAR Tech.
Note NCAR/TN-429+STR, National Center for Atmospheric Research, Boulder, Colorado, USA, 1996.

Boville, B. A. and Gent, P. R.: The NCAR Climate System Model, version one, J. Climate, 11, 1115-1130, 1998.

Brix, H., Gruber, N., and Keeling, C. D.: Interannual variability of the upper ocean carbon cycle at station ALOHA near Hawaii, Global Biogeochem. Cy., 18, GB4019, doi:10.1029/ 2004GB002245, 2004.

Caldeira, K. and Wickett, M. E.: Anthropogenic carbon and ocean pH, Nature, 425, p. 365, 2003.

Cao, L., Caldeira, K., and Jain, A. K.: Effects of carbon dioxide and climate change on ocean acidification and carbonate mineral saturation, Geophys. Res. Lett., 34, L05607, doi:10.1029/2006GL028605, 2007.

Conkright, M. E., Antonov, J. I., Boyer, T. P., Locarnini, R. A., O'Brien, T. D., Stephens, C., and Garcia, H. E.: World Ocean Atlas 2001, vol. 49-52 of NOAA Atlas NEDIS, US Govt. Printing Office, Washington, D. C., 2002.

Dickson, A.: Handbook of methods of the analysis of the various parameters of the carbon dioxide system in seawater, US Dep. of Energy, Washington, D. C., 2002.

Doney, S., Lindsay, K., Fung, I., and John, J.: Natural variability in a stable, 1000-yr global coupled climate-carbon cycle simulation, J. Climate, 19, 3033-3054, 2006.

Doney, S. C., Fabry, V. J., Feely, R. A., and Kleypas, J. A.: Ocean acidification: the other $\mathrm{CO}_{2}$ problem, Ann. Rev. Mar. Sci., 1, 169-192, doi:10.1146/annurev.marine.010908.163834, 2009.

Fabry, V. J.: Marine Calcifiers in a High- $\mathrm{CO}_{2}$ Ocean, Science, 320, 1020-1022, 2008.

Fabry, V. J., Seibel, B. A., Feely, R. A., and Orr, J. C.: Impacts of ocean acidification on marine fauna and ecosystem processes, ICES J. Mar. Sci., 65, 414-432, 2008.

Feely, R. A., Sabine, C. L., Kitack, L., Berelson, W., Kleypas, J., Fabry, V. J., and Millero, F. J.: Impact of Anthropogenic $\mathrm{CO}_{2}$ on the $\mathrm{CaCO}_{3}$ System in the Oceans, Science, 305, 362-366, 2004.

Feely, R. A., Sabine, C. L., Hernandez-Ayon, J. M., Ianson, D., and Hales, B.: Evidence for Upwelling of Corrosive "Acidified" Water onto the Continental Shelf, Science, 320, 1490-1492, doi: 10.1126/science.1155676, published online 22 May 2008, 2008.

Fine, M. and Tchernov, D.: Scleractinian Coral Species Survive and Recover from Decalcification, Science, 315, p. 1811, 2007.

Forster, P., Ramaswamy, V., Artaxo, P., Berntsen, T., Betts, R., Fahey, D. W., Haywood, J., Lean, J., Lowe, D. C., Myhre, G., Nganga, J., Prinn, R., Raga, G., Schulz, M., and Dorland, R. V.: Climate Change 2007: The Physical Science Basis. Contribution of Working Group I to the Fourth Assessment Report of the Intergovernmental Panel on Climate Change, chap. Changes in Atmospheric Constituents and in Radiative Forcing, Cambridge University Press, Cambridge, United Kingdom and New York, NY, USA, 129-234, 2007.

Friedlingstein, P., Cox, P., Betts, R., Bopp, L., Von Bloh, W., Brovkin, V., Cadule, P., Doney, S., Eby, M., Fung, I., Bala, G., John, J., Jones, C., Joos, F., Kato, T., Kawamiya, M., Knorr, W., Lindsay, K., Matthews, H. D., Raddatz, T., Rayner, P., Reick, C., Roeckner, E., Schnitzler, K. G., Schnur, R., Strassmann, K., Weaver, A. J., Yoshikawa, C., and Zeng, N.: Climate-Carbon Cycle Feedback Analysis: Results from the $\mathrm{C}^{4} \mathrm{MIP}$ Model Intercomparison: Evolution of carbon sinks in a changing climate, $\mathrm{J}$. Climate, 19, 3337-3353, 2006. 
Frölicher, T. L., Joos, F., Plattner, G. K., Steinacher, M., and Doney, S. C.: Natural variability and anthropogenic trends in oceanic oxygen in a coupled carbon cycle-climate model ensemble, Global Biogeochem. Cy., 23, 1-15, doi:10.1.1029/ 2008GB003316, 2009.

Fung, I., Doney, S., Lindsay, K., and John, J.: Evolution of carbon sinks in a changing climate, P. Natl. Acad. Sci. USA, 102, 11201-11206, 2005.

Gangstø, R., Gehlen, M., Schneider, B., Bopp, L., Aumont, O., and Joos, F.: Modeling the marine aragonite cycle: changes under rising carbon dioxide and its role in shallow water $\mathrm{CaCO} 3$ dissolution, Biogeosciences, 5, 1057-1072, 2008, http://www.biogeosciences.net/5/1057/2008/.

Gattuso, J.-P., Frankignoulle, M., Bourge, I., Romaine, S., and Buddemeier, R. W.: Effect of calcium carbonate saturation of seawater on coral calcification, Global Planet. Change, 18, 37-46, 1998.

Gehlen, M., Gangsttø, R., Schneider, B., Bopp, L., Aumont, O., and Ethe, C.: The fate of pelagic $\mathrm{CaCO}_{3}$ production in a high $\mathrm{CO}_{2}$ ocean: a model study, Biogeosciences, 4, 505-519, 2007, http://www.biogeosciences.net/4/505/2007/.

Gent, P. R., Bryan, F. O., Danabasoglu, G., Doney, S. C., Holland, W. R., Large, W. G., and McWilliams, J. C.: The NCAR Climate System Model global ocean component, J. Climate, 11, 12871306, 1998.

German Advisory Council on Global Change: The Future Oceans Warming up, Rising High, Turning Sour, WGBU Special Report, German Advisory Council on Global Change (WBGU), Berlin, Germany, 2006.

Guinotte, J., Orr, J., Cairns, S., Freiwald, A., Morgan, L., and George, R.: Will human-induced changes in seawater chemistry alter the distribution of deep-sea scleractinian corals?, Front. Ecol. Environ., 4, 141-146, 2006.

Heinze, C.: Simulating oceanic $\mathrm{CaCO}_{3}$ export production in the greenhouse, Geophys. Res. Lett., 31, L16308, doi:10.1029/ 2004GL020613, 2004.

Hoegh-Guldberg, O.: Low coral cover in a high- $\mathrm{CO}_{2}$ world, J. Geophys. Res., 110, C09S06, doi:10.1029/2004JC002528, 2005.

Holland, M. M., Bitz, C. M., and Tremblay, B.: Future abrupt reductions in the summer Arctic sea ice, Geophys. Res. Lett., 33, L23503, doi:10.1029/2006GL028024, 2006.

Iglesias-Rodriguez, M. D., Halloran, P. R., Rickaby, R. E. M., Hall, I. R., Colmenero-Hidalgo, E., Gittins, J. R., Green, D. R. H., Tyrrell, T., Gibbs, S. J., von Dassow, P., Rehm, E., Armbrust, E. V., and Boessenkool, K. P.: Phytoplankton Calcification in a High- $\mathrm{CO}_{2}$ World, Science, 320, 336-340, doi:10.1126/science. $1154122,2008$.

Jin, X., Gruber, N., Dunne, J. P., Sarmiento, J. L., and Armstrong, R. A.: Diagnosing the contribution of phytoplankton functional groups to the production and export of particulate organic carbon, $\mathrm{CaCO}_{3}$, and opal from global nutrient and alkalinity distributions, Global Biogeochem. Cy., 20, 2, GB2015, doi: 10.1029/2005GB002532, 2006.

Joos, F. and Spahni, R.: Rates of change in natural and anthropogenic radiative forcing over the past 20000 years, P. Natl. Acad. Sci. USA, 105, 1425-1430, 2008.

Jutterström, S. and Anderson, L. G.: The saturation of calcite and aragonite in the Arctic Ocean, Mar. Chem., 94, 101-110, 2005.

Key, R. M., Kozyr, A., Sabine, C. L., Lee, K., Wanninkhof, R.,
Bullister, J., Feely, R. A., Millero, F., Mordy, C., and Peng, T.H.: A global ocean carbon climatology: Results from Global Data Analysis Project (GLODAP), Global Biogeochem. Cy., 18, GB4031+, doi:10.1029/2004GB002247, 2004.

Kiehl, J. T., Hack, J. J., Bonan, G. B., Boville, B. A., Williamson, D. L., and Rasch, P. J.: The National Center for Atmospheric Research Community Climate Model, J. Climate, 11, 1151-1178, 1998.

Kleypas, J. A., Buddemeier, R. W., Archer, D., Gattuso, J.-P., Langdon, C., and Opdyke, B. N.: Geochemical Consequences of Increased Atmospheric Carbon Dioxide on Coral Reefs, Science, 284, 118-120, 1999.

Kleypas, J. A., Feely, R. A., Fabry, V. J., Langdon, C., Sabine, C. L., and Robbins, L. L.: Impacts of Ocean Acidification on Coral Reefs and Other Marine Calcifiers: A Guide for Future Research, report of a workshop held 18-20 April 2005, St. Petersburg, FL, sponsored by NSF, NOAA, and the US Geological Survey, 2006.

Kwon, E. Y. and Primeau, F.: Optimization and sensitivity of a global biogeochemistry ocean model using combined in situ DIC, alkalinity, and phosphate data, J. Geophys. Res.-Oceans, 113(C8), C08011, doi:10.1029/2007JC004520, 2008.

Langdon, C.: Review of Experimental Evidence for Effects of $\mathrm{CO}_{2}$ on Calcification of Reef builders, in: Proceedings 9th International Coral Reef Symposium, vol. 2, 1091-1098, 2002.

Langdon, C. and Atkinson, M. J.: Effect of elevated $\mathrm{pCO}_{2}$ on photosynthesis and calcification of corals and interactions with seasonal change in temperature/irradiance and nutrient enrichment, J. Geophys. Res., 110, C09S07, doi:10.1029/2004JC002576, 2005.

Lueker, T. J., Dickson, A. G., and Keeling, C. D.: Ocean $\mathrm{pCO}_{2}$ calculated from dissolved inorganic carbon, alkalinity, and equations for $\mathrm{K}-1$ and $\mathrm{K}-2$ : validation based on laboratory measurements of $\mathrm{CO}_{2}$ in gas and seawater at equilibrium, Mar. Chem. 70, 105-119, 2000.

Lüthi, D., Le Floch, M., Bereiter, B., Blunier, T., Barnola, J.-M., Siegenthaler, U., Raynaud, D., Jouzel, J., Fischer, H., Kawamura, K., and Stocker, T. F.: High-resolution carbon dioxide concentration record $650000-800000$ years before present, Science, 453 , 379-382, 2008.

Martin, J. H., Knauer, G. A., Karl, D. M., and Broenkow, W. W.: VERTEX - Carbon cycling in the Northeast Pacific, Deep-Sea Res., 34, 267-285, 1987.

McNeil, B. I. and Matear, R. J.: Climate change feedbacks on future oceanic acidification, Tellus B, 59, 191-198, 2007.

Meehl, G. A., Stocker, T. F., Collins, W. D., Friedlingstein, P., Gaye, A. T., Gregory, J. M., Kitoh, A., Knutti, R., Murphy, J. M., Noda A., Raper, S. C. B., Watterson, I. G., Weaver, A. J., and Zhao, Z.-C.: Climate Change 2007: The Physical Science Basis. Contribution of Working Group I to the Fourth Assessment Report of the Intergovernmental Panel on Climate Change, chap. Global Climate Projections, Cambridge University Press, Cambridge, United Kingdom and New York, NY, USA, 747-846, 2007.

Mehrbach, C., Culberson, C. H., Hawley, J. E., and Pytkowicz, R. M.: Measurement of apparent dissociation-constants of carbonic-acid in seawater at atmospheric-pressure, Limnol. Oceanogr., 18, 897-907, 1973.

Millero, F. J.: Thermodynamics of the carbon dioxide system in the oceans, Geochim. Cosmochim. Ac., 59, 661-677, 1995.

Mucci, A.: The solubility of calcite and aragonite in seawater at 
various salinities, temperatures and 1 atmosphere total pressure, Am. J. Sci., 238, 780-799, 1983.

Najjar, R. G., Jin, X., Louanchi, F., Aumont, O., Caldeira, K., Doney, S. C., Dutay, J.-C., Follows, M., Gruber, N., Joos, F., Lindsay, K., Maier-Reimer, E., Matear, R. J., Matsumoto, K., Mouchet, A., Orr, J. C., Sarmiento, J. L., Schlitzer, R., Weirig, M. F., Yamanaka, Y., and Yool, A.: Impact of circulation on export production, dissolved organic matter, and dissolved oxygen in the ocean: Results from Phase II of the Ocean Carboncycle Model Intercomparison Project (OCMIP-2), Global Biogeochem. Cy., 21, GB3007, doi:10.1029/2006GB002857, 2007.

Orr, J. C., Fabry, V. J., Aumont, O., Bopp, L., Doney, S. C., Feely, R. A., Gnanadesikan, A., Gruber, N., Ishida, A., Joos, F., Key, R. M., Lindsay, K., Maier-Reimer, E., Matear, R., Monfray, P., Mouchet, A., Najjar, R. G., Plattner, G.-K., Rodgers, K. B., Sabine, C. L., Sarmiento, J. L., Schlitzer, R., Slater, R. D., Totterdell, I. J., Weirig, M. F., Yamanaka, Y., and Yool, A.: Anthropogenic ocean acidification over the twenty-first century and its impact on calcifying organisms, Nature, 437, 681-686, 2005.

Orr, J. C., Jutterström, S., Bopp, L., Anderson, L. G., Fabry, V. J., Frölicher, T. L., Jones, P., Joos, F., Maier-Reimer, E., Segschneider, J., Steinacher, M., and Swingedouw, D.: Arctic ocean acidification, Nature, submitted, 2008.

Plattner, G.-K., Knutti, R., Joos, F., Stocker, T. F., von Bloh, W., Brovkin, V., Cameron, D., Driesschaert, E., Dutkiewiz, S., Eby, M., Edwards, N. R., Fichefet, T., Hargreaves, J. C., Jones, C. D., Loutre, M. F., Matthews, H. D., Mouchet, A., Müller, S. A., Nawrath, S., Price, A., Sokolov, A., Strassmann, K. M., and Weaver, A. J.: Long-term climate commitments projected with climate - carbon cycle models, J. Climate, 21, 2721-2751, doi: 10.1175/2007JCLI1905.1, 2008.

Prentice, I. C., Farquhar, G. D., Fasham, M. J. R., Goulden, M. L., Heimann, M., Jaramillo, V. J., Kheshgi, H. S., Le Quéré, C., Scholes, R. J., and Wallace, D. W. R.: Climate Change 2001: The Scientific Basis. Contribution of Working Group I to the Third Assessment Report of the Intergovernmental Panel on Climate Change, chap. The Carbon Cycle and Atmospheric Carbon Dioxide, Cambridge University Press, Cambridge, United Kingdom and New York, NY, USA, 183-237, 2001.

Randerson, J. T., Thompson, M. V., Conway, T. J., Fung, I. Y., and Field, C. B.: The contribution of terrestrial sources and sinks to trends in the seasonal cycle of atmospheric carbon dioxide, Global Biogeochem. Cy., 11, 535-560, 1997.

Revelle, R. and Suess, H. E.: Carbon dioxide exchange between atmosphere and ocean and the question of an increase of atmospheric $\mathrm{CO}_{2}$ during the past decades, Tellus, 9, 18-27, 1957.

Ridgwell, A., Zondervan, I., Hargreaves, J. C., Bijma, J., and Lenton, T. M.: Assessing the potential long-term increase of oceanic fossil fuel $\mathrm{CO}_{2}$ uptake due to $\mathrm{CO}_{2}$-calcification feedback, Biogeosciences, 4, 481-492, 2007, http://www.biogeosciences.net/4/481/2007/.

Royal Society: Ocean acidification due to increasing atmospheric carbon dioxide, Policy Document 12/05, Royal Society, London, 2005.

Sarmiento, J. L., Dunne, J., Gnanadesikan, A., Key, R. M., Matsumoto, K., and Slater, R.: A new estimate of the $\mathrm{CaCO}_{3}$ to organic carbon export ratio, Global Biogeochem. Cy., 16, 4, 1107, doi:10.1029/2002GB001919, 2002.
Schlitzer, R.: Ocean Data View (Software), http://odv.awi.de, 2007.

Schneider, K. and Erez, J.: The effect of carbonate chemistry on calcification and photosynthesis in the hermatypic coral Acropora eurystoma, Limnol. Oceanogr., 51, 1284-1293, 2006.

Siegenthaler, U., Stocker, T. F., Monnin, E., Lüthi, D., Schwander, J., Stauffer, B., Raynaud, D., Barnola, J.-M., Fischer, H., Masson-Delmotte, V., and Jouzel, J.: Stable carbon cycle-climate relationship during the late Pleistocene, Science, 310, 13131317, doi:10.1126/science.1120130, 2005.

Steinacher, M.: Ocean acidification and changes in marine productivity in simulations with the fully coupled 3-D climate model CSM1.4-carbon, Master's thesis, University of Bern, Bern, Switzerland, 2007.

Strassmann, K. M., Plattner, G.-K., and Joos, F.: $\mathrm{CO}_{2}$ and non- $\mathrm{CO}_{2}$ radiative forcings in climate projections for twentyfirst century mitigation scenarios, Clim. Dynam., doi:10.1007/ s00382-008-0505-4, published online 20 Dec 2008, 2008.

Stroeve, J., Holland, M. M., Meier, W., Scambos, T., and Serreze, M.: Arctic sea ice decline: Faster than forecast, Geophys. Res. Lett., 34, L09501, doi:10.1029/2007GL029703, 2007.

Takahashi, T., Olafsson, J., Goddard, J. G., Chipman, D. W., and Sutherland, S. C.: Seasonal-variation of $\mathrm{CO}_{2}$ and nutrients in the high-latitude surface oceans - a comparative-study, Global Biogeochem. Cy., 7, 843-878, 1993.

Taylor, K. E.: Summarizing multiple aspects of model performance in a single diagram., J. Geophys. Res.-Atmos., 106, 7183-7192, 2001.

Thomas, H., Prowe, A. E. F., van Heuven, S., Bozec, Y., de Baar, H., Schiettecatte, L.-S., Suykens, K., Koné, M., Borges, A. V., Lima, I. D., and Doney, S. C.: Rapid decline of the $\mathrm{CO}_{2}$ buffering capacity in the North Sea and implications for the North Atlantic Ocean, Global Biogeochem. Cy., 21, GB4001, doi: 10.1029/2006GB002825, 2007.

Van Vuuren, D. P., Meinshausen, M., Plattner, G.-K., Joos, F., Strassmann, K. M., Smith, S. J., Wigley, T. M. L., Raper, S. C. B., Riahi, K., de la Chesnaye, F., den Elzen, M., Fujino, J., Jiang, K., Nakicenovic, N., Paltsev, S., and Reilly, J. M.: Temperature increase of 21 st century mitigation scenarios, P. Natl. Acad. Sci. USA, 105, 15258-15262, doi:10.1073/pnas.0711129105, 2008.

Walsh, J. E.: A data set on Northern Hemisphere sea ice extent, World Data Center-A for Glaciology (Snow and Ice), Glaciological Data, Report GD-2, part 1, 49-51, 1978.

Wang, Y. M., Lean, J. L., and Sheeley, N. R.: Modeling the sun's magnetic field and irradiance since 1713, Astrophys. J., 625, 522-538, 2005.

Weatherly, J. W., Briegleb, B. P., Large, W. G., and Maslanik, J. A.: Sea Ice and Polar Climate in the NCAR CSM, J. Climate, 11, 1472-1486, 1998.

Yamanaka, Y. and Tajika, E.: The role of the vertical fluxes of particulate organic matter and calcite in the oceanic carbon cycle: Studies using an ocean biogeochemical general circulation model, Global Biogeochem. Cy., 10, 361-382, 1996. 